\title{
THE DEMOGRAPHY OF FAMILIES: \\ A REVIEW OF PATTERNS AND CHANGE
}

\author{
Pamela J. Smock \\ Department of Sociology \& Population Studies Center \\ University of Michigan-Ann Arbor \\ 500 S. State Street \\ Ann Arbor, MI 48109
}

Christine R. Schwartz

Department of Sociology

University of Wisconsin-Madison

4462 Sewell Social Science Building

1180 Observatory Drive

Madison, WI 53706

Acknowledgment note: This research was carried out using the facilities of the Center for Demography and Ecology at the University of Wisconsin-Madison (P2CHD047873) and the

This is the author manuscript accepted for publication and has undergone full peer review but has not been through the copyediting, typesetting, pagination and proofreading process, which may lead to differences between this version and the Version of Record. Please cite this article as doi: 10.1111/jomf.12612

This article is protected by copyright. All rights reserved. 
Population Studies Center at the University of Michigan (P2CHD041028). We are grateful to Kelsey Wright and Huixian Li for their very helpful research assistance.

Running Head: THE DEMOGRAPHY OF FAMILIES

\begin{abstract}
We review demographic trends and research on families in the United States, with a special focus on the last decade. We consider several topics: (1) marriage and remarriage; (2) divorce; (3) cohabitation; (4) fertility; (5) same-gender unions; (6) immigrant families; and (7) children's living arrangements. Throughout, we review both overall trends and patterns as well as those by social class and race-ethnicity. We discuss major strands of recent research, emphasizing emerging themes and promising directions. We close with a summary of central patterns and trends. We conclude that recent trends are not as uniform as they tended to be in earlier decades, making the description of family change increasingly complex.
\end{abstract}

Key Words: Cohabitation, Divorce, Family, Fertility, Marriage, Same-Sex Marriage 


\begin{abstract}
We say the home is in transition. So it is. It is moving away from what it was toward something that it is to be....it is not an institution usually at an equilibrium....It is always on the move....The home problem, therefore, is not one that we can finally solve. (Groves, 1925: pp. 228229)
\end{abstract}

A family life educator born in 1877, Ernest Groves observed that the family as an institution was in transition and never static, words that are just as apt then as they are today. Sixty-five years later, family demographer Larry Bumpass asked "What’s Happening to the Family?” (Bumpass,1990). The general public, researchers, and the media remain keenly interested in this question. Reporting results from a new survey at that time, the 1987-88 National Survey of Families and Households, Bumpass discussed shifts in family life. He spoke of the rise in 
divorce, the growth of cohabitation, and increases in non-marital childbearing. Twenty years after Bumpass in a 2010 review of family demographic trends in the U.S., Andrew Cherlin (2010) concluded that we are experiencing a growing disconnect between families and households. That is, given trends in cohabitation, divorce, repartnering and nonmarital childbearing, families have become less likely to reside in the same household. The most obvious example is that many fathers and children live apart. Despite a rapidly changing social landscape in the past decade, particularly with respect to the aftermath of the Great Recession, these themes have remained central to the study of the family.

There are at least two types of studies in the field of family demography. One is careful tracking and measurement of families at either a given time point or trends over time. This includes the documentation of family structure, family transitions such as marriage, marital dissolution, and childbearing, and socioeconomic characteristics of families (e.g., income and education levels). This documentation motive is important, providing solid knowledge on changes in the family landscape. The second is a focus on the social, cultural, and economic correlates, precursors, and consequences of family structure and transitions. Although a large portion of this review is geared towards documentation of recent changes in families, we also incorporate recent work focused on describing and understanding the precursors and consequences of family structure and transitions.

Conceptually, a subtheme of our review draws on the intersections between family patterns and inequality. The “diverging destinies” framework, articulated by McLanahan (2004), 
indicates that families are increasingly dissimilar across social class lines, often proxied by educational attainment Throughout our review, we also use terms such as social class, economic advantage, and so on. The economically advantaged experience more stable family forms such as marriage while the less privileged undergo more family instability. We broaden the diverging destinies framework to also consider family variation by race and ethnicity, another aspect of inequality and a topic of longstanding interest and importance in family research.

Our review is organized around trends and patterns in basic family demographic measures and events: marriage and remarriage, divorce, cohabitation, fertility, same-gender unions, immigrant families, and children’s living arrangements. Although fifty years ago research in family demography often fit neatly into one of these categories, a hallmark of more recent research is that it tends to crosscut categories (e.g., the implications of changes in marriage for children's living arrangements, the dissolution of same-gender marital and cohabiting unions), making the placement of recent research into categories not clear cut. Because of the broad scope of this review, we largely restrict ourselves to the United States. Given the varying nature of each topic not all sections adhere to an identical outline, but are organized roughly as follows. We begin with a discussion of trends and basic patterns, next turning to variation in trends and patterns by social class and race-ethnicity. We also highlight major research themes and explanations for changes in families, with a special focus on recent research and new directions. 
We aim to make this review accessible to a variety of audiences. One audience consists of scholars interested in families (or in one or more of our focal areas) who seek a summary of recent trends and research. We also hope this review is helpful to another audience: those wanting a succinct grounding in basic trends and research findings to inform qualitative scholarship.

\title{
MARRIAGE AND REMARRIAGE
}

\begin{abstract}
Marriage is highly regarded and a goal for most men and women in the United States. The vast majority of young people see marriage in their futures, and this has remained virtually unchanged for the past several decades. Among high school seniors in 1976, 74\% expected to marry in the future. In 2014, 79\% reported that they expected to marry at some point (Anderson, 2016).
\end{abstract}

Despite high levels of aspirations for marriage, there are trends signaling a retreat from marriage. Figure 1 shows that the percentage of adults living with a spouse has been falling steadily for decades. In 1967, 70\% of adults were living with a spouse compared with just 51\% in 2018 and declines over the past decade matched those in the 1990s and 2000s (U.S. Census Bureau, 2018a).

[Figure 1 about here.] 
Part of the decline in the percentage of married adults is due to large increases in age at first marriage. As shown in Figure 1, men and women are entering first marriages substantially later in life. Even the last decade has seen considerable change. In 2010, the median age at marriage was 28.2 for men and 26.1 for women. Just a few years later, in 2018, the analogous figures were 29.8 for men and 27.8 for women (U.S. Census Bureau, 2018b: Table MS-2). These numbers are historically unprecedented, at least since solid data have been collected that allow for estimates. Although some of the decline in the percentage of adults living with a spouse is due to delays in marriage, there have also been declines in the percent who ever marry. Estimates using data from 1988 suggest that $87 \%$ of women married at some point in their lives compared with $84 \%$ in $2000-2005$ and $80 \%$ in 2005-2010 (Schoen, 2016).

Population-level marriage trends obscure substantial differences by race and ethnicity and by education. One important research emphasis over the last few decades has been a growing Black-White gap in marriage in which African Americans have lower marriage rates than Whites (Lichter, McLaughlin, Kephart, \& Landry, 1992; Raley, Sweeney, \& Wondra, 2015; Wilson, 1987). In 1970, among 40-44 year-old women, $95 \%$ of White women had married as had $92 \%$ of African-American women. In contrast, data from 2008-2012 indicate that fewer than two-thirds of 40-44 year-old African-American women had ever married compared to $88 \%$ of White women (Raley et al., 2015). More generally, race-ethnic differences in the percentage of women who have ever married have grown. For example, Hispanic, American Indian/Native Alaskan, and African-American women all have increasingly different percentages of women marrying 
compared to White and Asian/Pacific Islander women and compared to one another (Raley et al., 2015).

Trends in the proportion of women ever marrying by education align with McLanahan’s (2004) observation that the economically advantaged are increasingly likely to experience stable family forms such as marriage relative to the less advantaged. Considering educational alone, in 2016, $27 \%$ of women without a high school education were currently married compared to nearly $60 \%$ of those with a college degree or more. Women with high school degrees or some college fell in between, with 45\% currently married (Allred, 2018). Among White women, college graduates were once less likely to have married than women with less education, but this gap gradually closed since 1960 due to increases in the percentage of White college graduate women marrying. Black college graduate women have also become more likely to ever marry relative to their less educated counterparts (Isen \& Stevenson, 2011).

Overall, trends by race-ethnicity and education since the 2000s represent a continuation of trends begun decades ago rather than a distinct new period of change (Isen \& Stevenson, 2011; Raley et al., 2015). Demographers and other social scientists in both the past decade, as well as in prior ones, have emphasized changes in the economy as a major reason for declines in marriage (Autor, Dorn, \& Hanson, 2018; Cherlin, 2014; Cherlin, Ribar, \& Yuasutake, 2016; Schneider, Harknett, \& Stimpson, 2019). People appear to tie marriage “readiness” to having a comfortable income, little to no debt, and a secure job. That is, marriage has come to be seen as a luxury good, a step to be taken after one has achieved a comfortable level of economic stability 
(Addo, 2014; Cherlin, 2004; Gibson-Davis, Gassman-Pines, \& Lehrman, 2018; Huang et al., 2011; Smock, Manning, \& Porter, 2005). Those markers of economic stability have become less available to those without college degrees as the number of well-paid, skilled manufacturing jobs has declined. Scores of studies have shown that the least educated, typically those with the worst economic prospects, are less likely to marry than the most educated (e.g., Addo, 2014; GibsonDavis et al., 2018; Ishizuka, 2018; Kuo \& Raley, 2016; Lundberg, Pollak, \& Stearns, 2016; Oppenheimer, 2003; Schneider et al., 2019; Smock \& Manning, 1997; Smock, Manning, \& Porter, 2005; Xie, Raymo, Goyette, \& Thornton, 2003). In addition to economic factors, marriage market availability and the increase in mass incarceration have also been leading explanations for trends and variation in marriage patterns (e.g., Charles \& Luoh, 2010; Cohen \& Pepin, 2018; Lichter et al., 1992; Raley et al., 2015; Schneider et al., 2019; Wilson, 1987; but see Lopoo \& Western, 2005).

Given the relationship between economic wellbeing and marriage, one might have expected the Great Recession (which officially began in 2007 and ended in 2009 although unemployment rates did not reach pre-recession levels until 2015) to have reduced marriage (Schneider, 2017). However, marriage rates continued their previous downward trajectory over this period with little evidence of perturbation; that is, marriage rates declined at the same rate they had been before the recession when we would have expected the recession to lead to a steeper decline (Cherlin, Cumberworth, Morgan, \& Wimer, 2013; Morgan, Cumberworth, \& Wimer, 2011). Research using state-level variation in the severity of the recession also finds little 
evidence of a recession effect, with the possible exception of small negative effects on the likelihood that women of low socioeconomic status marry (Morgan et al., 2011; Schneider \& Hastings, 2015). One possible reason for the recession's lack of apparent effect is that it is not only economics that matter for marriage. A key explanatory framework used to understand temporal changes in family patterns is the second demographic transition (SDT). SDT emphasizes that ideational factors (e.g., norms, attitudes), alongside economic changes, are vital for understanding why family life is decreasingly centered around marriage and supportive of other family forms (Lesthaeghe, 2014; Lesthaeghe \& Neidert, 2006; Lesthaeghe \& van de Kaa, 1986).

The future may well be characterized by a continued retreat from marriage. Consider the percentage marrying by age 40 for Generation X (i.e., those born between 1966 and 1972) (Martin, Astone, \& Peters, 2014). For Generation X women, 82\% married by age 40. Martin and colleagues projected that the percent married will decrease to $75 \%$ and $70 \%$ for early (b. 1980) and late (b. 1990) Millennials, respectively. The study also projects growing divergence by education in the percentage who marry with slow but steady declines in marriage for men and women with college degrees and faster declines for those without college degrees. As the authors state: “The singles are coming” (Martin et al., 2014, p. 4).

Although the percentage of men and women currently and ever married has declined, particularly among the less advantaged, remarriage is common because divorce remains common. About 34\% of ever-married men aged 60-69 in 2008-2012 had had two or more 
marriages as had 30\% of ever-married women (Lewis \& Kreider, 2015). There is also evidence of racial-ethnic and educational variation. McNamee and Raley (2011) estimate the number of years it takes for $25 \%$ of women in various subgroups to remarry using data from the mid-2000s. Black and Latina (both native- and foreign-born) women take longer to remarry than White women. By 3.8 years post separation, 25\% of White women have remarried. For both native- and foreign-born Latinas, the comparable number is slightly more than 5 years. For Black women, the data do not allow for an estimate: one quarter is never reached over the observation period. Remarriage rates are highest for those with some college or a bachelor's degree, and least common for high school dropouts (Payne, 2018).

There also appears to be a retreat from remarriage. Between 1950 and 2017, remarriage rates declined by more than one half (Schweizer, 2019). Importantly, this decline is not concentrated in the more distant past; the trend has continued into recent years (Schweizer, 2019; see also Payne, 2018; McNamee \& Raley, 2011; Sweeney, 2010). It holds for diverse groups such as Asian, Hispanic, White, Black, and native- and foreign-born men and women. To some extent, post-divorce cohabitation may be replacing remarriage. Entrance into cohabiting unions after divorce happens more much more quickly than entrance into remarriage (McNamee \& Raley, 2011). Within 1.7 to 2.8 years after divorce for all racial-ethnic-nativity subgroups, 25\% have entered a cohabiting union. This compares to 2.8 to 5.2 years for remarriage. Taken together, these findings are suggestive of a retreat from remarriage with cohabitation offsetting some of this decline (Brown \& Wright, 2017). An important implication of both remarriage and 
postdivorce cohabitation is that they create stepfamilies; most individuals who remarry or enter a postdivorce cohabitation have children from prior relationships.

\section{DIVORCE}

As Figure 2 shows, divorce rates increased slowly in the United States (with the exception of short period fluctuations) from the late 1800s through the early 1960s before surging upwards beginning in the 1960s. Since the late 1970s, divorce rates—-the number of divorces per 1,000 married women — have remained high. Estimates of the lifetime percentage of marriages that dissolve — which includes both separation and divorce—from 1980 indicate that $44 \%$ of marriages would dissolve compared with 43-46\% in 2005-2010 (Schoen, 2016; Schoen \& Standish, 2001). Vital statistics data from state administrative records suggest that divorce rates declined from the late 1970s through the mid-1990s, but the deteriorating quality of these data may partially account for this (Kennedy \& Ruggles, 2014). However, data from the American Community Survey (ACS), an in-depth U.S. Census Bureau survey with data on divorce since 2008, lend additional support to the argument that divorce rates have declined. Further, in the last decade, ACS data indicate a steeper decrease in divorce rates than in previous decades.

[Figure 2 about here.]

Declines in divorce among young adults are largely responsible for recent declines in divorce rates. The divorce rate among younger adults declined between 1990 and 2010 and has 
continued to decline since then (Cohen, 2018; Kennedy \& Ruggles, 2014). One group that has not seen declines in divorce, but rather an increase, is older Americans, a shift coined the "grey divorce revolution.” Between 1990 and 2010 the divorce rate among those aged 50 and older more than doubled, albeit beginning from a low baseline (Brown \& Lin, 2012). The grey divorce revolution is largely driven by Baby Boomers who were also more likely to divorce than their predecessors at younger ages (Brown \& Lin, 2012; Brown \& Wright, 2017). Cohen (2018) suggests the decline of divorce rates among younger adults may foreshadow lower divorce rates in the future. Moreover, given ever-later ages of first marriage, those who do marry young may be an increasingly select group of highly committed couples. In addition, the aging of the population implies increasing numbers of older married couples who tend to have lower (although increasing) divorce rates than younger married couples. Kennedy and Ruggles (2014) show that this compositional shift has dampened divorce trends-divorce rates would have been substantially higher since the 1980s if not for the aging of the married population. Thus, the increasing selectivity of couples into marriage and the aging of the married population are vital factors to consider when interpreting trends in divorce.

Like other demographic patterns, trends in marital dissolution have diverged by education. This divergence began among those married in the 1980s when education differences in divorce existed but were substantially smaller and continued among those married into the early 2000s (Martin, 2006; Schwartz \& Han, 2014). Recent estimates indicate stark educational differences in marital dissolution as measured by either separation or divorce, whichever 
occurred first. The probability of marital dissolution after twenty years of marriage in 2006-2012 was $22 \%$ for college graduates but $51 \%$ for those with some college, $59 \%$ for high school graduates, and $61 \%$ for those without a high school diploma or GED (Copen, Daniels, Vespa, \& Mosher, 2012:Table 5). The highly educated have increasingly stable marriages relative to their less educated counterparts in a number of other countries as well including Austria, France, Spain, Sweden, the Netherlands, Korea, and Taiwan (Cheng, 2016; Park \& Raymo, 2013; Garriga \& Cortina, 2017; Matysiak, Styrc, \& Vignoli, 2014; Härkönen \& Dronkers, 2006; de Graaf \& Kalmijn, 2006).

There is some indication, however, that the educational divergence in marital dissolution is not the same across populations-in the U.S., for instance, education differences in marital dissolution have not grown as quickly and are not nearly as large for Black women as for White women (Kim, 2012). Differences in marital dissolution between Black and White women, however, have increased. Before 1920, race differences in divorce were relatively small, but they increased substantially between the 1960s and 1990s (Bramlett \& Mosher, 2002; Ruggles, 1997; Sweeney \& Phillips, 2004; Raley et al., 2015). Estimates of the lifetime percentage of marriages that dissolve from the late 2000s indicate that Black women's marriages are more likely to dissolve than other women's; 73\% of Black women's first marriages are estimated to dissolve within twenty years compared with $46 \%$ of White women's, $47 \%$ of Hispanic women's, and 31\% of Asian women's (Copen et al., 2012). 
An area that has received renewed attention over the last decade because of interest in the effects of the Great Recession is the link between economic cycles and divorce. Since the early 2000s, the relationship between divorce rates and unemployment rates has been negative; that is, when unemployment went down, the divorce rate went up and when unemployment went up (as during the Great Recession), divorce rates went down (Cohen, 2014; Schaller, 2013). As is the case for marriage, these effects were small, and evidence suggests that on balance the recession may have delayed marital dissolutions rather than led people to forgo them altogether (Cherlin et al., 2013; Schaller, 2013). One study finds that when men become unemployed while separated from their wives, legal divorce tends to be delayed. Thus, the Great Recession may have delayed divorce among those already separated (Tumin \& Qian, 2017), potentially explaining some of the decline in divorce rates since 2008 (Figure 2). The convention among family demographers is to study marital dissolution starting from the time of separation rather than relying on the date of a legal divorce. Those in economic straits may only divorce if remarriage is on the horizon. Whether better economic times will result in an uptick in divorce or whether these declines are part of a longer-term trend driven by declines in divorce among younger adults and increased selection into marriage remains to be seen.

\section{COHABITATION}


The U.S. is past the time when being unmarried meant being "single.” People are waiting longer to marry and if they marry at all, they are not delaying living with an intimate partner (Kuperberg, 2014; Lamidi \& Manning, 2016). The proportion of adults living with a differentgender unmarried partner has increased steadily since cohabitation measurement began in the 1960s, with a speed-up in the trend beginning in the late 1970s (Smock, 2000; U.S. Census Bureau 2018a). Thus, the central story of different-gender cohabitation over the past decade is that the prominence of living together outside of marriage continues to increase.

There are other ways to grasp the cohabitation trend. It is often demonstrated by examining the percentage of people who report having ever cohabited. Questions asking whether one has ever cohabited are preferable to describe people's cohabitation experience. Because cohabitation tends to be a short-term state, with marriage or dissolution occurring within a few years, snapshot measures of current cohabitation status underestimate the prevalence of cohabitation in people’s lives. Among women aged 25-29, 49\% had ever cohabited in 1995, rising to a striking $73 \%$ in 2011-13. While those with college educations are somewhat less likely to have cohabited, the majority of women in all education groups had cohabited by their late mid-to-late 20s (Lamidi \& Manning, 2016).

Cohabitation is not solely the province of the young. Among older adults, defined as those 50 and up, cohabitation has also increased. In 2000 there were approximately 1.2 million men and women age 50 and up in cohabiting relationships (Brown, Bulanda, \& Lee, 2005). By 2014, that number was 3.2 million (Hemez \& Brown, 2016). We do not know the percentage of 
older adults who have ever cohabited. To date, data sources do not provide the requisite information to calculate that figure.

Another way researchers gauge the increasing prominence of cohabitation is via the proportion of marriages that begin as cohabiting relationships. Among women who first married between 1980 and 1984, two-fifths lived with their spouses first. Among those marrying between 2010 and 2014, a far higher 70\% lived with their spouses beforehand. Figure 3 shows that, consistent with other demographic patterns, there is an educational divide, with more educated women more likely to forgo premarital cohabitation than less educated women. Among those marrying between 2010 and 2014, 85\% of those without a high school degree lived with their spouse before marriage compared to 63\% of those with at least a bachelor's degree (Hemez \& Manning, 2017). Figure 3 also shows that the education gradient in cohabitation has grown across cohorts. Racial-ethnic differences in the percentage of adults who cohabit prior to marriage are small: the numbers are 70\%, 77\%, and 73\% for non-Hispanic Whites, non-Hispanic Blacks, and Hispanics. The major point is that most people who marry are cohabiting first.

[Figure 3 about here.]

Recent research has examined social class differences in other aspects of cohabitation. Sassler, Michelmore, and Qian (2018), for example, investigate the pace of entry into cohabitation. Women from more advantaged backgrounds are not only less likely to cohabit, but among those that do, the pace of entry into coresidence is slower than for less advantaged women. In addition, college educated women who had cohabited were more likely to transition 
into marriage than less advantaged women (Sassler et al., 2018; see also Sassler \& Miller, 2017). There is also evidence of educational divergence in the role of cohabitation in people's lives in Canada. Wright (2018) found that Canadians without a bachelor's degree are more likely to have a child within cohabitation and that marriage chances for the less educated have sharply decreased.

While most cohabiting couples marry or dissolve their relationships fairly quickly, within two to three years, recent studies suggest a trend toward lower chances of marriage and higher levels of dissolution. Mernitz (2018) studied two cohorts of cohabitors. The later cohort represents those born between 1980 and 1984, while the earlier one consists of those born between 1957 and 1964. Only 32\% of the more recent cohort married within five years of the start of cohabitation compared to $41 \%$ of the earlier cohort. There is also a slight cohort differential in terms of breaking up: 52\% of the more recent cohort broke up within five years of living together compared to 49\% of the earlier cohort (see also Guzzo, 2014; Kuo \& Raley, 2016; Lamidi, Manning, \& Brown, 2019).

Thus, it appears that cohabitation has become less a "stepping stone” to marriage and this is especially so for those who are not economically advantaged. This is consistent with the numerous studies across the past two decades or so showing that the well-off are more likely to transition from cohabitation to marriage than those in less salutary economic situations (e.g., Smock \& Manning,1997; Ishizuka, 2018; Xie et al., 2003). In fact, serial cohabitation - 
cohabiting more than once - has been rising and is more prevalent among the less educated (Eickmeyer \& Manning, 2018; Lichter \& Qian, 2008; Lichter, Turner \& Sassler, 2010).

Another focus of recent research is childbearing and childrearing within cohabiting unions. Studies suggests a continued “decoupling” of marriage and childbearing as cohabitation becomes an increasingly normative context for having children. Roughly $40 \%$ of nonmarital births were to cohabiting couples in 2010-2014. In fact, the increase in nonmarital births is due to the increase in births to cohabiting couples and not to increases in non-union childbearing (Lamidi, 2016; Wu, 2017). The share of all births to cohabiting mothers has grown from just 6\% in 1980-1984 to 26\% in 2010-2014. The increase cuts across all racial and ethnic groups as well as education levels, although highly educated women remain unlikely to have nonmarital births. At the same time, the share of births to single, non-cohabiting women has been stable over the last few decades. It has hovered around 15-18\% between the early 1980s and the early 2010s. In 2010-14, the percentage was 15\% (Wu, 2017).

A new development is emerging evidence from several studies that cohabitation appears to no longer decrease marital stability. Two decades ago, the vast majority of studies showed a positive correlation between premarital cohabitation and marital dissolution (Smock, 2000). Those who cohabited before marriage faced higher risks of divorce. The purported mechanisms were that cohabitors were a select group of the population with more liberal attitudes, including attitudes towards divorce. Another explanation was that there is something about the experience of cohabitation itself that leads people to learn that intimate family relationships are not solely 
defined by marriage. In the early 2000s, studies emerged showing that the negative cohabitation effect did not apply to all racial and ethnic subgroups. Phillips and Sweeney (2005), for example, found that non-Hispanic White women who cohabited were more likely to experience divorce but that this was not so for non-Hispanic Black or Mexican-American women.

In the last decade, several articles were published suggesting that the "cohabitation effect" had by and large disappeared and that those who cohabit before marriage are no longer more vulnerable to divorce than others (Copen et al., 2012; Kuperberg, 2014; Manning \& Cohen, 2012; Musick \& Michelmore, 2015). Reinhold (2010), for example, even finds that cohabitation can stabilize remarriages. A possible explanation for these newer findings is that as cohabitation now has a normative presence, it no longer serves as a marker of more or less stable marriages. Research on other countries similarly suggests that as cohabitation becomes more normative, the effects of premarital cohabitation on the risk of divorce risk diminish (Liefbroer \& Dourleijn, 2006). Although the weight of evidence is in the direction of little or no association between premarital cohabitation and divorce, one recently published article finds that the positive association between premarital cohabitation and marital dissolution persists (Rosenfeld \& Roesler, 2019).

\section{FERTILITY}


Figure 4 shows that fertility rates in the United States declined precipitously after the Baby Boom (i.e., 1947-1964) through the early 1970s and have been relatively stable since then. Fertility rates increased slightly between the mid-1990s and 2007 but have since fallen to record lows (Hamilton, Martin, Osterman, Driscoll, \& Rossen, 2019). In 2018, the fertility rate was 59.0 births per 1,000 women age 15-44 compared with 69.3 in 2007 (Hamilton et al., 2019; Martin, Hamilton, Osterman, Driscoll, \& Mathews, 2017). Low points from previous eras were higher than current levels. For example, Figure 4 shows that fertility rates in the midst of the Great Depression were higher than they were in 2018. Much of the decline in fertility since 2007 is due to declines in births among young women. Births to women age 40 and over increased, but not enough to counteract the decline among women in their teens and twenties. Teen births have been dropping especially rapidly and are at historic lows (Hamilton et al., 2019). Since 2007, fertility rates have also declined across a broad array of race-ethnic groups including for White, Black, American Indian and Alaska Native, and Asian and Pacific Islander women, and declines were especially large for Hispanic women (Martin et al., 2017).

[Figure 4 about here.]

Despite these declines, the United States still has higher total fertility rates than most European countries, although it has not had above replacement-level fertility (above 2.1) since 2007 and was 1.8 births per woman on average as of 2017 (World Bank, 2019). In 2017, the number of births per woman in the United States was slightly lower than in Sweden, Ireland, and France among a few other OECD countries, but higher than in Belgium, Norway, and Germany, 
for example. An active area of research over the last decade investigates reasons for crossnational variation in fertility rates, often citing the ease or difficulty with which women combine work and family responsibilities (e.g., Esping-Andersen \& Billari, 2015; McDonald, 2013).

The decline in fertility since 2007 is small relative to larger historical shifts but has inspired an active literature on the whether the decline might be due to the Great Recession. The consensus is that the Great Recession did reduce fertility somewhat among younger women (see Schneider, 2017; Sobotka, Skirbekk, \& Philipov, 2011 for reviews), but there is not consensus about whether the decline represents a temporary postponement or whether the total number of children women eventually have will be negatively affected by the recession (Astone, Martin, \& Peters, 2015; Cherlin et al., 2013; Currie \& Schwandt, 2014; Seltzer, 2019). Because the recession affected the fertility of younger rather than older women, there is still time for completed fertility rates to rebound (Cherlin et al., 2013). In addition, a key component in the decline in fertility was a large drop in fertility among Hispanic immigrants. Because the recession was associated with considerable reductions in Hispanic immigration--in particular, migration from Mexico (Villarreal, 2014)--the Hispanic immigrant population has aged over this period. Thus, rather than a direct response to economic hardship among those already in the U.S., the shifting composition of the immigrant population away from peak childbearing years may be responsible for a substantial portion of the decline in Hispanic immigrant fertility (Cherlin et al., 2013; Parrado, 2011). Despite an official end to the recession in 2009 and increased employment, fertility has continued to decline. Longer-term structural changes, especially the 
decline of manufacturing and construction, also depress fertility; thus fertility rates may be unlikely to rebound soon (Seltzer, 2019).

Unlike notable divergence by education in marriage and divorce patterns, trends in fertility differentials by education are less apparent. Women with more education have long had fewer children on average than those with less education, and these differentials have remained relatively stable (Isen \& Stevenson, 2011; Martinez, Daniels, \& Febo-Vazquez, 2018). Yet there are indications that some change has occurred. Although remaining lower than among those with less education, fertility rates among college educated women (in particular, those with advanced degrees) have increased (Hayford, 2013; Hazan \& Zoabi, 2015; Livingston, 2015; Shang \& Weinberg, 2013; Vere, 2007). Some research has pointed to the greater ability of highly educated women to outsource especially as the relative price of childcare for highly educated women has fallen whereas it has increased the less educated (Hazan \& Zoabi, 2015). In addition, among highly educated women, the availability of child care has increased and their spouses participate more in childcare (Antecol, 2015; Shang \& Weinberg, 2013). The timing of women’s fertility by education has also diverged with college graduates delaying childbirth more than less educated women (McLanahan, 2004). In recent cohorts, women with at most a high school degree have often completed childbearing by their late 20s, an age at which college graduates are just beginning to have children (Cherlin, Talbert, \& Yasutake, 2014).

A large proportion of births occur outside marriage. After increasing steadily since the 1960s, the percentage of births to unmarried women has been relatively stable since 2008, with 
40\% of all births to unmarried women in 2016 (Child Trends, 2018). Births to unmarried mothers are far more common among mothers with less education. In 2009-2013, the proportion of births to unmarried mothers with less than a high school degree was $68 \%$ compared with $11 \%$ for college educated mothers (Manning et al., 2015). Whereas education differences in nonmarital and unintended fertility have clearly increased over time (England, Shafer, \& Wu, 2012; Hayford \& Guzzo, 2016), differences in nonmarital fertility between White and Black women have shrunk somewhat because non-marital births have increased more for White women than for Black women. Non-marital births grew for White women from 21\% in 1995 to 29\% in 2016 whereas they were 70\% for Black women in both 1995 and 2016 (after fluctuating somewhat in the intervening years) (Child Trends, 2018). At the same time, differences between White and Hispanic women have increased because non-marital births increased faster for Hispanic women (42\% in 1995 to 53\% in 2016) than White women (Child Trends, 2018; Manning, Brown, \& Stykes, 2014). Differences in marital fertility rates and timing have also declined between Black and White women (Hayford, Guzzo, \& Smock, 2014) as have total fertility rates for White, Black, and Hispanic women (Sweeney \& Raley, 2014).

The rise of nonmarital childbearing and family instability is also linked to an increase in "multiple-partner" fertility (MPF), which is defined as having children with more than one partner. MPF existed in the past—6\% of White married couples experienced MPF in 1955 (Zobl \& Smock, 2015)—but it has increased markedly and is now less associated with marital fertility within stepfamilies and more associated with nonmarital fertility (Stykes \& Guzzo, 2019). 
Among parents, recent estimates of MPF generally fall in the $14 \%$ to $25 \%$ range depending on the data source and age restrictions (Guzzo, 2014; Monte, 2019; Scott, Peterson, Ikramullah, \& Manlove, 2013; Stykes \& Guzzo, 2019). But among unmarried parents, estimates are substantially higher (Cancian, Meyer, \& Cook, 2011; Fomby \& Osborne, 2017; Guzzo, 2014). Monte (2019) provides national prevalence estimates and reports that in cohabiting families with children, MPF is $43.6 \%$. MPF is also more common among socioeconomically disadvantaged men and women, those who had their first births at young ages, and in populations and contexts where union dissolution rates are high (Carlson \& Furstenberg, 2006; Monte, 2019; Thomson, Lappegard, Carlson, Evans, \& Gray, 2014). There is also evidence that MPF has increased in the recent past and will continue to increase into the future given that younger cohorts of men and women are transitioning into MPF sooner than older cohorts (Guzzo, 2014).

\section{SAME-GENDER UNIONS}

On June 26, 2015, in a landmark case the Supreme Court ruled in favor of marriage equality (Obergefell v. Hodges, 2015). Before that time, several states allowed same-gender couples to marry, but the 2015 decision made same-gender marriage legal in all states. Same-gender marriage increased after Obergefell $v$. Hodges but pinning down the effect of the decision is methodologically difficult. This stems from the fact that same-gender marriage was available in several states and the District of Columbia prior to Obergefell v. Hodges, and that different data 
sources and assumptions affect estimates. In 2016, there were 486,994 married same-gender couples, which were relatively evenly split between female and male couples (roughly 251,000 and 235,000, respectively) (U.S. Census Bureau, 2016). By 2017, estimates based on nationally representative data from a Gallup Poll in combination with Census data indicate that the total number of married same-gender couples had increased to 547,000 (Romero, 2017). Some scholars would argue that this is too low; a study also based on Gallup survey data suggested that even in 2015 there were as many as 780,000 same-gender married couples (Gates \& Newport, 2015). Focusing only on married same-gender couples also underestimates the number of coresidential same-gender couples given that, as is true for different-gender couples, many samegender couples are cohabiting. In 2017, there were roughly 380,000 same-gender cohabiting couple households. Like married same-gender households, these are fairly evenly split between female and male couple households (U.S. Census Bureau, 2017a).

Same-gender couples tend to be more socioeconomically advantaged on a number of dimensions than different-gender couples. For example, married same-gender couples have higher levels of schooling than their different-gender counterparts. In 34\% of these same-gender married couples, both spouses have a college degree or more; for different-gender married couples, both spouses have at least a college degree in only one-quarter of cases. Married samegender couples are also more likely to have both partners employed (57\% vs. $49 \%$ ), are somewhat more likely to self-identify as White ( $84 \%$ vs. $81 \%$ ) and less likely to self-identify as Black, Asian, or Hispanic, and have higher median household incomes. In 2017, median 
household income for different-gender married couples was $\$ 88,683$ versus $\$ 98,889$ for samegender married couples. Cohabiting same-gender couples are also more likely to be college graduates, be employed, self-identify as White, and have higher median incomes than differentgender cohabitors (U.S. Census Bureau, 2017a).

Notably, there is a substantial gender disparity in the incomes of same-gender couples. In 2017 , annual income for female married couples was roughly $\$ 90,000$ compared to a substantially higher $\$ 111,000$ for male married couples (U.S. Census Bureau, 2017a). Fisher, Gee, \& Looney (2018) used federal tax records on annual income in 2015 and find similar results: female married couples had median adjusted gross incomes of $\$ 90,531$ compared with $\$ 109,788$ for male married couples and $\$ 79,966$ for different-gender married couples. This gender disparity among same-gender married couples does not appear to be accounted for by employment or by education. For the two groups, the percent in which both spouses are employed is almost identical and there is only a trivial difference in educational attainment: in $35.7 \%$ of male married households and $33.5 \%$ of female married households both spouses have at least a bachelor's degree. The male income advantage among same-gender couples also holds among same-gender cohabiting couples (U.S. Census Bureau, 2017a ).

Same-gender couples, married or unmarried, are less likely to be raising children than different-gender couples. Only 19\% of married and 13\% of unmarried same-gender couples are raising children compared to 39\% of married and 38\% of unmarried different-gender couples (U.S. Census Bureau, 2017a). In addition, childrearing is much more common among female 
than male couples. More than twice as many female couples have children (24\%) than their male counterparts (9\%) (U.S. Census Bureau, 2017a; see also Gates, 2015). Childrearing is also more common among African-American, Latino, and Native American/Alaskan than among White same-gender couples. For example, $40 \%$ of African-American same-gender couples have children under 18 in the home compared to $16 \%$ of White same-gender couples (Gates, 2012). Compared to different-gender couples, the education gradient in parenthood for samegender couples is much larger. In 2009, unmarried same-gender couples with a high school diploma were somewhat less likely than comparably educated different-gender couples to have children in the home (32\% vs. 41\%), but same-gender couples with college degrees were dramatically less likely to have children in the home (10\% vs. 47\%) (Gates, 2012: Figure 3). Thus, same-gender couples with children in the home tend to have less education, lower median incomes, and higher poverty rates than different-gender parents despite the fact that same-gender couples as a whole have higher incomes and education than different-gender couples (Albelda, Badgett, Schneebaum, \& Gates, 2013; Fisher et al., 2018; Gates, 2012; Gates, 2015; Rosenfeld, 2010). When differences in couples' education and other characteristics predictive of poverty are controlled, one study using data from 2010-2013 found that children in female couple households have similar rates of poverty as their counterparts in different-gender couple households (Brown, Manning, \& Payne, 2016); but others found that even after controlling for similar characteristics, female-couple households were more likely to be poor (Albelda et al., 2013; Schneebaum \& Badgett, 2019). Data that include information on sexual orientation show 
that controlling for education, demographic, marital status, and health measures, lesbians and gay men are not more likely to be poor than heterosexuals, but bisexual women and men are statistically significantly more likely to be poor (Badgett, 2018).

There are also indications of a decline in parenthood among same-gender couples since 2006, stemming from a decrease in births from prior different-gender relationships; this mirrors trends in the general population (see Figure 4). Although the majority of children living with same-gender parents are biological or step-children of one of the partners, rates of adoption and fostering are much higher among same- than different-gender couples (Gates, 2012, 2015). Yet the decline in births from prior relationships outpaced increases in adoption, fostering, and reproductive technologies, leading to an overall decline in parenthood among same-gender couples since the mid-2000s (Gates, 2015).

Relationship dissolution patterns among same-gender couples have been actively studied over the past decade. Perhaps the most important observation is that to date, there are no studies that directly compare dissolution rates among legally married same-gender and different-gender couples in the United States. A fairly consistent finding is that same-gender couples, (including both cohabitors and married couples), and in particular, female couples, have higher dissolution rates than different-gender couples (e.g., Joyner, Manning, \& Bogle, 2017; Kolk \& Andersson, 2018; Lau, 2012; Wiik, Seierstad, \& Noack, 2014). One reason is that despite the current legality of same-gender marriage, same-gender couples remain less likely than different-gender couples to be married and marriage is a more stable relationship type than cohabitation or dating 
(Joyneret al., 2017; Rosenfeld, 2014). Tracking trends in dissolution patterns is an important area of future research.

\section{IMMIGRANT FAMILIES}

In 2017, 44.4 million people in the United States were immigrants, often termed “foreign born”, representing $13.6 \%$ of the U.S. population (Radford, 2019). Immigration to the United States surged in the 1980s through the early 2000s along with the share of the population that is foreign born (Office of Immigration Statistics, 2017: Table 1; Radford \& Noe-Bustamante, 2019). Since the Great Recession, legal immigration has leveled off and the size of the undocumented immigrant population has remained relatively constant or declined somewhat, depending on the estimate (Massey, 2012; Office of Immigration Statistics, 2017: Table 1; 2018: Figure 1; Radford \& Noe-Bustamante, 2019).

Despite the leveling of immigration into the United States, the share of the population that is foreign born has grown since the 1970s and reached 14\% in 2017 (compared with a high of almost 15\% in 1890) (Radford, 2019). Over this period, the composition of immigrant flows have changed. In the early 2000s, most immigrants arriving in the United States were from the Americas, Mexico in particular, but immigration from Mexico has declined since the Great Recession and immigration from Asia has increased (Massey, 2012; Passel, Cohn, \& GonzalezBarrera, 2012; Radford \& Noe-Bustamante, 2019; Villarreal, 2014). As of 2017, the largest 
groups of immigrants are from South and East Asia (27\%), Mexico (25\%), other countries in Latin America (25\%), and Europe or Canada (13\%) (Radford \& Noe-Bustamante, 2019). What are the basic family patterns of immigrants? First, marriage is common in this population. Among those at least 18 years old in 2017, nearly 61\% of those born outside of the U.S. were currently married. This compares to $48 \%$ among those born in the U.S. (Radford \& Noe-Bustamante, 2019). It should be noted that these figures are based on a marital status question so do not capture past experience, only present circumstances. Part of the reason marriage prevalence is higher for the foreign born is because they are younger and in prime ages for marriage.

Second, marital dissolution is not unusual. Life table estimates using data from 20062010 suggest that $26 \%$ of married foreign-born Hispanics will separate (due to marital discord) or divorce within 10 years of marriage compared with $32 \%$ of marriages in the general population (Copen et al., 2012). The percentage of the foreign born currently divorced or separated has increased slowly over the past several decades, from 9\% in 1990 to 11\% in 2017 (Radford \& Noe-Bustamante, 2019). These numbers conceal a good deal of heterogeneity. For example, almost $20 \%$ of those from the Caribbean were separated or divorced, compared to $7 \%$ of those from South and East Asia (Radford \& Noe-Bustamante, 2019).

Tougher immigration enforcement associated with deportation is also a cause of family separation (Amuedo-Dorantes \& Arenas-Arroyo, 2019; Amuedo-Dorantes, Pozo, \& Puttitanum, 2015). For example, Amuedo-Dorantes and Arenas-Arroyo (2019) find that increases in 
immigration enforcement between 2005 and 2015 increased the likelihood that undocumented mothers live without their spouses by 20\%and the likelihood that Hispanic U.S.-born children live without their parents by $19 \%$. Family separations associated with deportation are associated with increased poverty, fear, stress, anxiety, and depression (Dreby, 2012, 2015; Hagan, Rodríguez, \& Castro, 2011; Rodríguez \& Hagan, 2004; Suárez-Orozco, Bang, \& Kim, 2011). Non-migrant mothers that are left behind in their origin country also experience distress when their spouses migrate to the U.S. (Nobles, Rubalcava, \& Teruel, 2015).

Third, immigrants play a large role in fertility in the U.S. After increasing steadily for decades, the number of U.S. births to foreign-born mothers declined between 2007 and 2014, a trend that also held for births to undocumented immigrants (Livingston, 2016; Passel \& Cohn, 2016). As noted in the fertility section of this article, birth rates among immigrant women fell more rapidly than those for U.S.-born women in the wake of the Great Recession, thereby contributing to an overall decline in fertility rates. Nevertheless, births to foreign-born women still comprise a large portion of all births in the U.S. In 2014, 23\% of U.S.-born babies had foreign-born mothers. Most of these births were to women born in Latin America (54\%), but the share of births to women born in Latin America has declined since 2010 while the share of births to Asian mothers has increased alongside migration from Asia (Livingston, 2016).

Recent research has also shown that births to foreign-born women are compensating for declining births among U.S.-born women in a number of states (including North Carolina, Florida, Washington, and Nebraska among others) (Livingston, 2017). A combination of low 
birth rates, population aging, and increased mortality among the non-Hispanic U.S. population means that Hispanic migration and fertility have been important in offsetting population decline in many locations. Further, because immigration to the U.S. from Mexico has declined and a smaller share of new immigrants are from the Americas (Radford \& Noe-Bustamante, 2017) this means that Hispanic immigration contributes proportionately less to U.S. population growth than in the past, thereby increasing the relative contribution of Hispanic fertility (Johnson \& Lichter, 2013, 2016). If immigration declines in the future, the relative contribution of Hispanic fertility versus in-migration to U.S. population growth might increase further. But a countervailing factor could be the tendency for fertility to be higher among recent immigrants and lower among second and third generation immigrants in the U.S. (Carter, 2000; Choi, 2014; Parrado, 2011), a pattern also found in Europe (e.g., Dubuc, 2012; Kulu et al., 2017).

Another area of research concerns trends and patterns of intermarriage between immigrants and the native-born; intermarriage has often been used to gauge the extent to which immigrants form intimate social ties with the native-born. Over the past decade, researchers have increasingly focused on differences in immigrant-native intermarriage rates by country of origin rather than classifying immigrants into panethnic groups (Alba \& Foner, 2015; Kalmijn, 2012; Lichter, Qian, \& Tumin, 2015; Qian, Glick, \& Batson, 2012). A major finding from this research is that immigrants from some countries are more likely to marry across ethnic lines the longer they have been in the U.S. and across successive generations. Other immigrant groups, however, 
sustain much lower intermarriage rates across generations despite high education and earnings (Lichter et al., 2015).

Scholars have also increasingly taken advantage of new survey data (questions included since 2008 in the American Community Survey) on the timing of marriage and migration. Prior research has generally focused on marriages occurring since immigrants’ arrival in the United States. Recent research, however, shows that this approach ignores substantial proportions of intermarriages that occur either before the immigrant spouse migrated to the United States or occurred in the same year of migration. In 2010-2014, 46\% of immigrant women married to native-born U.S. citizens married prior to or in the same year as migration (Balistreri, Joyner, \& Kao, 2017: Figure 1). These findings suggest that migration and marriage are often intertwined processes (Balistreri et al., 2017; Stevens, Ishizawa, \& Escandell, 2012). Unlike in the 2000s when researchers documented declines in intermarriage between foreign-born Hispanics and native-born whites (Qian \& Lichter, 2007), little research has examined trends in intermarriage between the foreign- and native-born in the current decade. Given changing migration patterns, this is a fruitful avenue for future research.

\section{CHILDREN'S LIVING ARRANGEMENTS}

Children’s living arrangements reflect the family transitions of their parents. As we have underscored, change continues to occur in many realms relevant to children. Parents divorce, 
have children in cohabiting relationships or on their own, and enter new marital or cohabiting relationships.

Taking the long view, children's living arrangements have changed substantially. For example, in 1970, 12\% of all children lived in single-parent families, the vast majority of which were mother-only families. By 2018, 27\% did so (U.S. Census Bureau, 2018c: Table CH1). A more specific portrait is as follows. In 2016, the proportion of all children living in a twobiological parent married household stood at $60 \%$. Roughly $3 \%$ lived in a two-parent biological cohabiting family, $9 \%$ in a step-parent family, $24 \%$ in a single-parent family, and the remainder in other arrangements. Of the $9 \%$ of children living in a stepfamily, approximately $55 \%$ are in step-parent married families and $45 \%$ are in cohabiting stepfamilies. Among the $24 \%$ of children living in single-parent families, the vast majority live with their mother; only 3\% live in a singlefather family (Eickmeyer, 2017b, 2017c).These numbers are virtually identical to those for 2010 indicating little change in the past decade (Eickmeyer, 2017a).

Although only 9\% of children were living in a step-parent family in 2016, stepkin are a more prominent feature of U.S. families than this rather low percentage suggests. The formation of stepfamilies in childhood also extends into individuals' adult lives. A recent study estimates that $30 \%$ of U.S. households contain a tie to an adult stepchild or stepparent (e.g., adults have a stepchild in the household or have a stepparent in another household) (Wiemers, Seltzer, Schoeni, Hotz, \& Bianchi, 2019). The prevalence of stepkin ties is substantially higher among 
younger households (i.e., head of household is less than 55 years old) than older households (37\% versus 19\%), consistent with the trends covered in this review.

Consistent with the growing diversity of family forms, children are also increasingly likely to live with a grandparent. In 1970 , the share was $3.2 \%$, rising to $8 \%$ in 2015 . While these percentages are small, almost $30 \%$ of all children in the U.S. have coresided with a grandparent at some point during childhood (Amorim, Dunifon, \& Pilkauskas, 2017). While the majority of children living with a grandparent also live with their parent(s) (i.e., a three-generation household), 25\% live with their grandparent without a parent in the household. This latter configuration is termed a "skipped-generation" household.

There is substantial variation along the lines of social class and race-ethnicity. The general upshot is that economics and family structure play out in a way that disadvantages children with less privileged backgrounds and underrepresented minorities. Consider children in two biological-parent families; this includes both married and cohabiting couple families. Among those in married families, 53\% have a parent with at least a college degree, compared to 15\% of children in biological cohabiting families (Eickmeyer, 2017a). Data collected in 2017 are also indicative of a social class divide (U.S. Census Bureau, 2017b). Among parents with a bachelor's degree or more, $88 \%$ are married. In contrast, among parents without a high school degree, 67\% are married (see also Stykes \& Williams, 2013). In addition, skipped-generation households tend to be more economically vulnerable than three-generational households. Over 
$30 \%$ of children in skipped-generation households live in poverty compared to $17 \%$ in threegenerational households (Wu, 2018).

White families are more likely to be in family structures associated with low poverty rates. In 2018, $70 \%$ of White children lived in two-parent married families compared to $36 \%$ of Black children, $85 \%$ of Asian children, and 61\% of Hispanic children (data constraints preclude information for detailed Hispanic and Asian subgroups) (U.S. Census Bureau, 2018c:Table C3). Poverty rates for children vary as follows: $12 \%$ for non-Hispanic White, $26 \%$ for Hispanic, $12 \%$ for Asian, and 30\% for Black children (U.S. Census Bureau, 2018d). There are exceptions to these general patterns. For example, some Asian groups are economically advantaged, but Asian children are more likely to live in three-generation households than Black and Hispanic children (Amorim et al., 2017; see also Pilkauskas \& Cross, 2018).

Although cross-sectional snapshots of children's living arrangements are useful, family researchers are more engaged with documenting and understanding children's experiences as they unfold over time. While this has been a major research theme for more than two decades, it continues to be a very active area of current research. It is one thing to say that a certain percentage of children live in a particular family structure, but another to track their experiences over the course of their childhoods. This interest stems not only from the goal of demographic accuracy and detail, but from a large number of studies suggesting that family structure instability is typically not advantageous for children in the United States (e.g., Brown, 2010; Bzostek \& Berger, 2017; Lee \& McLanahan, 2015). 
Given the trends we have reviewed here, it is unsurprising that many children experience a good deal of family instability. There are two concepts and measures that researchers are using to study these issues. Family instability generally refers to parents and children, occurring when a parent leaves or a new parent-figure moves in. The child may also experience other changes such as moving in (or out) with a grandparent or other relative, but these changes have received less attention overall in the instability literature. The other concept is family complexity; studies of family complexity are largely an achievement of the past decade (Carlson and Meyer, 2014; Meyer \& Carlson, 2014). Typically this work focuses on complex sibling composition (half siblings, step-siblings) or integrates both sibling and complex-parent configurations (singleparent, step-parent) (Fomby, Goode, \& Mollborn, 2016; Fomby \& Osborne, 2017; Manning et al., 2014). Complexity in sibling composition is driven by multiple partner fertility in which one parent or step-parent has children from more than one relationship (Guzzo, 2014).

Two recent studies examine the prevalence of family instability and/or complexity for children over time. Using data on children born between 1985 and 2010, Rackin and GibsonDavis (2018) find that family instability has plateaued for children with highly educated mothers, but has increased for less-advantaged children. Contrasting children’s family situations in 1996 and 2009, another study concludes that there has been a plateau in family complexity (Manning et al., 2014).

Research on family instability and complexity and their linkages to child wellbeing will likely to continue in the foreseeable future. One emerging direction is that researchers are 
increasingly taking account of other key social, health, and demographic concepts and measures when studying children's family experiences and wellbeing. Some specific examples include a study of father loss and telemore length published in the journal Pediatrics by an interdisciplinary team including family demographers, a developmental psychologist, and a pediatrician who specializes in genetics and children's health (Mitchell et al., 2017). Fowler, Henry, and Marcal (2015) examined both family and housing instability and their connections to adolescent criminal activity (see also, Bosick \& Fomby, 2018; Cavanagh et al., 2018; Gaydosh \& Harris, 2018; Mitchell et al., 2015). Perkins (2019) provides a fresh perspective on the concept of instability by focusing on household instability involving non-relatives. Her work shows that studies on only family instability miss roughly $20 \%$ of children’s experiences of instability. Moreover, household instability has a negative association with children's educational attainment on par in magnitude with family instability.

\section{DISCUSSION}

In 1990, Larry Bumpass asked “What’s Happening to the Family?”, concluding that families have undergone revolutionary changes and that these changes were unlikely to reverse (Bumpass, 1990). Trends in the 1970s and early 1980s certainly pointed in this direction-declining marriage rates, increases in cohabitation and non-marital births, declining fertility, and large increases divorce. In contrast, Bianchi and Casper (2000) interpreted the mid- to late 1990s 
a period of “a 'quieting' of family change” with smaller changes in many family patterns than in earlier decades.

The current decade has similarly witnessed smaller changes or stabilization in some trends and continuation of others, making it more difficult to provide a general characterization of family change over this period. With regard to marriage, trends suggesting a retreat from marriage appear to have continued at a generally similar pace as in previous decades. The average age at marriage for men and women has continued its upward trajectory and is now at unprecedented levels and the proportions of adults living in marital relationships has continued to decline while the proportion living in cohabiting relationships has increased. In addition, fewer cohabitors are transitioning to marriage.

Unlike the 1970s when divorce rates increased rapidly, divorce rates have remained high but have declined since the early 1980s. Although a number of scholars have made this observation, there has been some doubt about the validity of a decline given the deteriorating quality of vital statistics data on divorce (Kennedy \& Ruggles, 2014). New analyses using data from the American Community Survey, however, show a continuation of previous declines and a somewhat sharper drop since 2008 (Figure 2; Cohen, 2018), lending support to the decline interpretation. One of the main drivers of this decline has been a drop in divorce among younger adults, suggesting potential future declines (Cohen, 2018). In contrast, divorce among older Americans has increased--the "grey divorce” revolution. Also contributing to the decline in divorce is the aging of the married population (Kennedy \& Ruggles, 2014) because despite "grey 
divorce," older married couples remain less likely than younger couples to divorce. In addition, fewer couples are getting married. Thus, the married population, particularly young married couples, may be increasingly comprised of those who are highly committed and less likely to divorce. Potential selection and age composition effects are important to keep in mind when interpreting trends, but it is also noteworthy that when Bumpass (1990) was reflecting on basic demographic trends, including trends in divorce, they all pointed in the same direction. This is less true today.

Fertility trends have shown more stability than change over the past decade. Since the large decline in fertility after the Baby Boom, fertility rates have been relatively stable. Still, the small drop since 2007 has brought U.S. fertility rates to record lows. Notably, although U.S. fertility is high relative to many developed nations, it is below replacement and moving down in the rankings. It appears that the Great Recession may have played a role in the recent decline along with declining Hispanic immigration (Cherlin et al., 2013). Although the number of U.S. births to foreign-born mothers declined substantially between 2007 and 2014, a large proportion of U.S. births occur to foreign-born women, and births to foreign-born women offset population decline in many areas of the U.S. (Livingston, 2016, 2017; Passel \& Cohn, 2016). Whether fertility rates will rebound is an open question.

We have seen striking change over the past few decades in the context in which fertility occurs, but this trend may be "quieting." The percentage of births to unmarried women increased steadily since the 1960s but has been relatively stable since 2008 (Child Trends, 2018). This is 
also true for the share of non-marital births to cohabiting women--after increasing steadily, the percentage of non-marital births to cohabiting women has plateaued in the past decade at roughly 63\% (Wu, 2017). Although recent trends in non-marital fertility may have “quieted,” there is some evidence that instability in children's living arrangements has continued to increase, at least for less economically privileged children. Multiple partner fertility has risen, and is common among disadvantaged women (Guzzo, 2014; Rackin \& Gibson-Davis, 2018). Yet there is also evidence of a possible plateau in children's experiences of family complexity (Manning et al., 2014). Discrepancies in findings and interpretations are sensitive to the time points being compared. Looking over the longer-term, and not just this past decade, children's family experiences have changed dramatically. More work on family complexity is needed, especially studies including very recent data.

The 2010s has also seen a growing literature on same-gender unions, the most recent work catalyzed by the landmark Supreme Court ruling in favor of marriage equality. Unsurprisingly, now that it is legal in all states, there has been an increase in same-gender marriage. A growing number of studies in the past decade have examined relationship quality or dissolution among same- and different-gender couples. To our knowledge, there is no research to date directly comparing dissolution chances among legally married same- and different-gender couples in the United States. This will be an important avenue for future research, once samegender marriage has been in place nationally longer. In addition, researchers should continue to track and update trends in the basic demographic characteristics of same-gender couples (e.g., 
Black, Gates, Sanders, \& Taylor, 2000). Further, as population-representative data on gender identity and sexual orientation become more widely available, demographers will be better able to describe the families of LGBTQ persons (Baumle, 2018). Studies of transgender individuals have already begun to appear in demographic journals (Lagos, 2018).

A major theme throughout our review has been “diverging destinies” (McLanahan, 2004). There is evidence for the continuation of this trend. The highly educated experience more marriage, more cohabitations that lead to marriage, less divorce, less family instability, and less nonmarital fertility. There are also distinct family patterns by race and ethnicity, with Whites and Asians experiencing less nonmarital childbearing and more marriage than Hispanics and African Americans. Part of these differences, as researchers have noted, stem from inequalities in socioeconomic status. The more privileged population subgroups, such as Whites and Asians, have more institutionalized family arrangements.

In closing, we make two observations. First, one cannot understand or contextualize social phenomena without studying families. Whether one is interested in inequality, raceethnicity, emerging adulthood, mortality, dating, or immigration, families cannot be ignored. To take an example, as is well known, social inequality is reproduced and maintained across generations. Thus, family change is necessary for studying, and vital for understanding, social stratification and inequality (e.g., Bloome, 2017; Maralani, 2013).

Second, the family is continually changing, as observed by many family scholars and by educator Ernest Groves almost a century ago, whom we quoted at the start of this review: "We 
say the home is in transition. So it is...The home problem, therefore, is not one that we can finally solve” (1925: pp. 228-229). Family change may be becoming even more complex in that trends in the recent past do not always point in the same direction or appear as uniform as in earlier decades. 


\section{REFERENCES}

Addo, F. R. (2014). Debt, cohabitation, and marriage in young adulthood. Demography, 51(5), 1677-1701. doi:10.1007/s13524-014-0333-6

Alba, R., \& Foner, N. (2015). Mixed unions and immigrant-group integration in North America and Western Europe. The Annals of the American Academy of Political and Social Science, 662(1), 38-56. doi:10.1177/0002716215594611

Albelda, R., Badgett, M. L., Schneebaum, A., \& Gates, G. J. (2013). Poverty in the lesbian, gay, and bisexual community. UCLA CCPR Population Working Papers. The Williams Institute UCLA School of Law. Los Angeles. Retrieved from https://williamsinstitute.law.ucla.edu/research/census-lgbt-demographics-studies/lgbtpoverty-update-june-2013/

Allred, C.A. (2018). Marriage: More than a century of change, 1900-2016. National Center for Family and Marriage Research. Bowling Green, OH. Retrieved from https://doi.org/10.25035/ncfmr/fp-18-17.

Amuedo-Dorantes, C., Arenas-Arroyo, E. (2019). Immigration enforcement and children’s living arrangements. Journal of Policy Analysis and Management, 31(1), 11-40. doi:

10.1002/pam.22106

This article is protected by copyright. All rights reserved. 
Amuedo-Dorantes, C., Pozo, S., Puttitanum, T. (2015). Immigration enforcement, parent-child separations, and intent to remigrate by Central American deportees. Demography, 52(6), 1825-1851. doi:10.1007/s13524-015-0431-0

Amorim, M., Dunifon, R., \& Pilkauskas, N. (2017). The magnitude and timing of grandparental coresidence during childhood in the United States. Demographic Research, 37(52), 16951706. doi:10.4054/DemRes.2017.37.52

Anderson, L. R. (2016). High school seniors' expectations to marry. National Center for Family and Marriage Research. Bowling Green, OH. Retrieved from https://scholarworks.bgsu.edu/cgi/viewcontent.cgi?article=1056\&context=ncfmr_family_ profiles

Antecol, H. (2015). Career and family choices among elite liberal arts graduates. Demography, 52(4), 1089-1120. doi:10.1007/s13524-015-0408-z

Astone, N. M., Martin, S., \& Peters, H. E. (2015). Millennial childbearing and the recession. Center on labor, relations, and population brief. Urban Institute. Washington, D.C. Retrieved from https://www.urban.org/sites/default/files/publication/49796/2000203Millennial-Childbearing-and-the-Recession.pdf

Autor, D., Dorn, D., \& Hanson, G. H. (2018). When work disappears: Manufacturing decline and the falling marriage-market value of young men. IZA Discussion Papers, No. 11465. Institute of Labor Economics. Bonn, Germany. Retrievedfrom https://www.econstor.eu/bitstream/10419/180483/1/dp11465.pdf

This article is protected by copyright. All rights reserved. 
Badgett, M. V. L. (2018). Left out? Lesbian, gay, and bisexual poverty in the U.S. Population Research and Policy Review, 34(5), 667-702. doi: 10.1007/s11113-018-9457-5

Balistreri, K. S., Joyner, K., \& Kao, G. (2017). Trading youth for citizenship? The spousal age gap in cross-border marriages. Population and Development Review, 43(3), 443-466. doi: 10.1111/padr.12072

Baumle, A. K. (2018). The demography of sexuality. In D. L. Compton, T. Meadow, \& K. Schilt (Eds.), Other, Please Specify: Queer Methods in Sociology (pp. 277-290). Oakland, CA: University of California Press.

Bianchi, S.M. \& Casper, L.M. (2000). American families. Population Bulletin (Population Reference Bureau). 55(4), 1-46. Retrieved from https://www.prb.org/wpcontent/uploads/2000/12/ACFAC41.pdf

Black, D., Gates, G., Sanders, S., \& Taylor, L. (2000). Demographics of the gay and lesbian population in the United States: Evidence from available systematic data sources. Demography, 37(2), 139-154. doi:10.2307/2648117

Bloome, D. (2017). Childhood family structure and intergenerational income mobility in the United States. Demography, 54(2), 541-569. doi:10.1007/s13524-017-0564-4

Bosick, S. J., \& Fomby, P. (2018). Family instability in childhood and criminal offending during the transition into adulthood. American Behavioral Scientist, 62(11), 1483-1504. doi:10.1177/0002764218787000

This article is protected by copyright. All rights reserved. 
Bramlett, M. D., \& Mosher, W. D. (2002). Cohabitation, marriage, divorce, and remarriage in the United States. Vital Health Statistics, 23(22), 1-32. Retrieved from https://www.cdc.gov/nchs/data/series/sr_23/sr23_022.pdf

Brown, S. L. (2010). Marriage and child well-being: Research and policy perspectives. Journal of Marriage and Family, 72(5), 1059-1077. doi:10.1111/j.1741-3737.2010.00750.x

Brown, S. L., Bulanda, J. R., \& Lee, G. R. (2005). The significance of nonmarital cohabitation: Marital status and mental health benefits among middle-aged and older adults. The Journals of Gerontology Series B: Psychological Sciences and Social Sciences, 60(1), S21-S29. doi:10.1093/geronb/60.1.S21

Brown, S. L., \& Lin, I.-F. (2012). The gray divorce revolution: Rising divorce among middleaged and older adults, 1990-2010. The Journals of Gerontology: Series B: Psychological Sciences and Social Sciences, 67(6), 731-741. doi:10.1093/geronb/gbs089

Brown, S. L., Manning, W. D., \& Payne, K. K. (2016). Family structure and children’s economic well-being: Incorporating same-sex cohabiting mother families. Population Research and Policy Review, 35(1), 1-21. doi:10.1007/s11113-015-9375-8

Brown, S. L., \& Wright, M. R. (2017). Marriage, cohabitation, and divorce in later life. Innovation in Aging, 1(2). doi:10.1093/geroni/igx015

Bumpass, L. L. (1990). What's happening to the family? Interactions between demographic and institutional change. Demography, 27(4), 483-498. doi:10.2307/2061566

This article is protected by copyright. All rights reserved. 
Bzostek, S. H., \& Berger, L. M. (2017). Family structure experiences and child socioemotional development during the first nine years of life: Examining heterogeneity by family $\quad$ structure at birth. Demography, 54(2), 513-540. doi: 10.1007/s13524-017-0563-5

Charles, K. K., \& Luoh, M. C. (2010). Male incarceration, the marriage market, and female outcomes. The Review of Economics and Statistics, 92(3), 614-627. doi:10.1162/REST_a_00022

Cancian, M., Meyer, D. R., \& Cook, S. T. (2011). The evolution of family complexity from the perspective of nonmarital children. Demography, 48(3), 957-982. doi:10.1007/s13524011-0041-4

Carlson, M. J., \& Furstenberg, F. F. (2006). The prevalence and correlates of multipartnered fertility among urban US parents. Journal of Marriage and Family, 68(3), 718-732. doi:10.1111/j.1741-3737.2006.00285.x Carlson, M. J., \& Meyer, D. R. (2014). Family complexity: Setting the context. The ANNALS of $\quad$ the American Academy of Political and Social Science, 654(1), 6-11. doi:10.1177/0002716214531378

Carter, M. (2000). Fertility of Mexican immigrant women in the US: A closer look. Social Science Quarterly, 81(4), 1073-1086.

This article is protected by copyright. All rights reserved. 
Cavanagh, S. E., Stritzel, H., Smith, C., \& Crosnoe, R. (2018). Family instability and exposure to violence in the early life course. Journal of Research on Adolescence, 28(2), 456-472. doi:10.1111/jora.12347

Cheng, Y.-h. A. (2016). More education, fewer divorces? Shifting education differentials of divorce in Taiwan from 1975 to 2010. Demographic Research, 34(1), 927-942. doi:10.4054/DemRes.2016.34.33

Cherlin, A., Cumberworth, E., Morgan, S. P., \& Wimer, C. (2013). The effects of the Great Recession on family structure and fertility. The Annals of the American Academy of Political and Social Science, 650(1), 214-231. doi:10.1177/0002716213500643

Cherlin, A. J. (2004). The deinstitutionalization of American marriage. Journal of Marriage and Family, 66(4), 848-861. doi:10.1111/j.0022-2445.2004.00058.x

Cherlin, A. J. (2010). Demographic trends in the United States: A review of research in the 2000s. Journal of Marriage and Family, 72(3), 403-419. doi:10.1111/j.17413737.2010.00710.x

Cherlin, A. J. (2014). Labor's love lost: The rise and fall of the working-class family in America. New York: Russell Sage Foundation.

Cherlin, A. J., Ribar, D. C., \& Yasutake, S. (2016). Nonmarital first births, marriage, and income inequality. American Sociological Review, 81(4), 749-770.

doi:10.1177/0003122416653112

This article is protected by copyright. All rights reserved. 
Cherlin, A. J., Talbert, E., \& Yasutake, S. (2014). Changing fertility regimes and the transition to adulthood: Evidence from a recent cohort. Paper presented at the annual meeting of the Population Association of America, Boston, MA.

Child Trends. (2018). Births to unmarried women. Child Trends. Washington, D.C. Retrieved from https://www.childtrends.org/indicators/births-to-unmarried-women

Choi, K. (2014). Fertility in the context of Mexican migration to the United States: A case for incorporating the pre-migration fertility of immigrants. Demographic Research, 30(24), 703-738. doi:10.4054/DemRes.2014.30.24

Cohen, P. N. (2014). Recession and divorce in the United States, 2008-2011. Population Research and Policy Review, 33(5), 615-628. doi:10.1007/s11113-014-9323-z

Cohen, P. N. (2018). The coming divorce decline. SocArXiv. Retrieved from https://osf.io/preprints/socarxiv/h2sk6/

Cohen, P. N., Pepin, J. R. (2018). Unequal marriage markets: Sex ratios and first marriage among Black and White women. Socius 4, 1-10. doi: 2378023118791084

Copen, C. E., Daniels, K., Vespa, J., \& Mosher, W. D. (2012). First marriages in the United States: Data from the 2006-2010 National Survey of Family Growth. National Health Statistics Report, (49), 1-21. National Center for Health Statistics. Hyattsville, MD. Retrieved from https://www.cdc.gov/nchs/data/nhsr/nhsr049.pdf

This article is protected by copyright. All rights reserved. 
Currie, J., \& Schwandt, H. (2014). Short- and long-term effects of unemployment on fertility. Proceedings of the National Academy of Sciences, 111(41), 14734-14739. doi:10.1073/pnas.1408975111

de Graaf, P. M., \& Kalmijn, M. (2006). Change and stability in the social determinants of divorce: A comparison of marriage cohorts in the Netherlands. European Sociological Review, 22(5), 561-572. doi:10.1093/esr/jcl010

Dreby, J. (2012). The burden of deportation on children in Mexican immigrant families. Journal of Marriage and Family, 74(4), 829-845. doi:10.1111/j.1741-3737.2012.00989.x

Dreby, J. (2015). U.S. Immigration policy and family separation: The consequences for children’s well-being. Social Science \& Medicine, 132, 245-251.

doi:10.1016/j.socscimed.2014.08.041

Härkönen, J., \& Dronkers, J. (2006). Stability and change in the educational gradient of divorce. A comparison of seventeen countries. European Sociological Review, 22(5), 501-517. doi:10.1093/esr/jcl011

Huang, P. M., Smock, P. J., Manning, W. D., \& Bergstrom-Lynch, C. A. (2011). He says, she says: Gender and cohabitation. Journal of Family Issues, 32(7), 876-905. doi:10.1177/0192513X10397601

Dubuc, S. (2012). Immigration to the UK from high-fertility countries: Intergenerational adaptation and fertility convergence. Population and Development Review, 38(2), 353368. doi:10.1111/j.1728-4457.2012.00496.x

This article is protected by copyright. All rights reserved. 
Eickmeyer, K. J. (2017a). American children's family structure: Two biological parent families. National Center for Family and Marriage Research. Bowling Green, OH. Retrieved from https://www.bgsu.edu/content/dam/BGSU/college-of-arts-andsciences/NCFMR/documents/FP/eickmeyer-two-biological-parent-families-fp-17-15.pdf

Eickmeyer, K. J. (2017b). American children's family structure: Stepparent families. National Center for Family and Marriage Research. Bowling Green, OH. Retrieved from https://www.bgsu.edu/content/dam/BGSU/college-of-arts-andsciences/NCFMR/documents/FP/eickmeyer-stepparent-families-fp-17-16.pdf

Eickmeyer, K. J. (2017c). American children's family structure: Single-parent families. National Center for Family and Marriage Research. Bowling Green, OH. Retrieved from https://www.bgsu.edu/content/dam/BGSU/college-of-arts-andsciences/NCFMR/documents/FP/eickmeyer-single-parent-families-fp-17-17.pdf

Eickmeyer, K. J., \& Manning, W. D. (2018). Serial cohabitation in young adulthood: Baby Boomers to Millennials. Journal of Marriage and Family, 80(4), 826-840. doi:10.1111/jomf.12495

England, P., Shafer, E. F., \& Wu, L. L. (2012). Premarital conceptions, postconception ("shotgun") marriages, and premarital first births: Education gradients in U.S. cohorts of white and black women born 1925-1959. Demographic Research, 27(6), 153-166. doi:10.4054/DemRes.2012.27.6

This article is protected by copyright. All rights reserved. 
Esping-Andersen, G., \& Billari, F. C. (2015). Re-theorizing family demographics. Population and Development Review, 41(1), 1-31. doi:10.1111/j.1728-4457.2015.00024.x

Fisher, R., Gee, G., \& Looney, A. (2018). Same-sex married tax filers after Windsor and Obergefell. Demography, 55(4), 1423-1446. doi:10.1007/s13524-018-0684-5

Fomby, P., Goode, J. A., \& Mollborn, S. (2016). Family complexity, siblings, and children's aggressive behavior at school entry. Demography, 53(1), 1-26. doi:10.1007/s13524-0150443-9

Fomby, P., \& Osborne, C. (2017). Family instability, multipartner fertility, and behavior in middle childhood. Journal of Marriage and Family, 79(1), 75-93. doi:10.1111/jomf.12349

Fowler, P. J., Henry, D. B., \& Marcal, K. E. (2015). Family and housing instability: Longitudinal impact on adolescent emotional and behavioral well-being. Social Science Research, 53, 364-374. doi:10.1016/j.ssresearch.2015.06.012

Garriga, A., \& Cortina, C. (2017). The change in single mothers' educational gradient over time in Spain. Demographic Research, S21(61), 1859-1888. doi:10.4054/DemRes.2017.36.61

Gates, G. J. (2012). Family formation and raising children among same-sex couples. Report FF51, F2-F4. National Council on Family Relations. Saint Paul, MN. Retrieved from https://williamsinstitute.law.ucla.edu/wp-content/uploads/Gates-Badgett-NCFR-LGBTFamilies-December-2011.pdf

This article is protected by copyright. All rights reserved. 
Gates, G. J. (2015). Demographics of married and unmarried same-sex couples: Analyses of the 2013 American Community Survey. The Williams Institute UCLA School of Law. Los Angeles. Retrieved from https://williamsinstitute.law.ucla.edu/wpcontent/uploads/Demographics-Same-Sex-Couples-ACS2013-March-2015.pdf

Gates, G. J., \& Newport, F. (2015). An estimated 780,000 Americans in same-sex marriages. Gallup. Washington, D.C. Retrieved from http://www.gallup.com/poll/182837/estimated780-000-americans-sex-marriages.aspx

Gaydosh, L., \& Harris, K. M. (2018). Childhood family instability and young adult health. Journal of Health and Social Behavior, 59(3), 371-390. doi:10.1177/0022146518785174

Gibson-Davis, C., Gassman-Pines, A., \& Lehrman, R. (2018). "His" and "hers": Meeting the economic bar to marriage. Demography, 55(6), 2321-2343. doi:10.1007/s13524-0180726-z

Groves, E. R. (1925). Social influences affecting home life. American Journal of Sociology, 31(2), 227-240. doi:10.1086/213854

Guzzo, K. B. (2014). New partners, more kids: Multiple-partner fertility in the United States. Annals of the American Academy of Political and Social Science, 654(1), 66-86. doi:10.1177/0002716214525571

Hagan, J. M. , Rodriguez, N., \& Castro, B. (2011). Social effects of mass deportations by the United States government, 2000-10. Ethnic and Racial Studies, 34(8), 1374-1391. doi:10.1080/01419870.2011.575233

This article is protected by copyright. All rights reserved. 
Haines, M. R. (2006). Marriage and divorce rates: 1920-1995. In S. B. Carter, S. S. Gartner, M. R. Haines, R. S. Olmstead, \& G. Wright (Eds.), Historical statistics of the United States, earliest times to the present: Millennial edition (pp. 1-688; 681-689). New York: Cambridge University Press.

Hamilton, B. E., Martin, J. A., Osterman, M. J., Driscoll, A. K., \& Rossen, L. M. (2018). Births: provisional data for 2017. Vital Statistics Rapid Release, Report 004. National Center for Health Statistics, Division of Vital statistics. Atlanta, GA. Retrieved from https://www.cdc.gov/nchs/data/vsrr/report004.pdf.

Hamilton, B. E., Martin, J. A., Osterman, M. J., \& Rossen, L. M. (2019). Births:

provisional data for 2018. Vital Statistics Rapid Release, Report 007. National Center for Health Statistics, Division of Vital statistics. Atlanta, GA. Retrieved from https://www.cdc.gov/nchs/data/vsrr/vsrr-007-508.pdf.

Hayford, S. R. (2013). Marriage (still) matters: the contribution of demographic change to trends in childlessness in the United States. Demography, 50(5), 1641-1661. doi:10.1007/s13524-013-0215-3

Hayford, S. R., \& Guzzo, K. B. (2016). Fifty years of unintended births: Education gradients in unintended fertility in the US, 1960-2013. Population and Development Review, 42(2), 313-341. doi:10.1111/j.1728-4457.2016.00126.x

This article is protected by copyright. All rights reserved. 
Hayford, S. R., Guzzo, K. B., \& Smock, P. J. (2014). The decoupling of marriage and parenthood? Trends in the timing of marital first births, 1945-2002. Journal of Marriage and Family, 76(3), 520-538. doi:10.1111/jomf.12114

Hazan, M., \& Zoabi, H. (2015). Do highly educated women choose smaller families? The Economic Journal, 125(587), 1191-1226. doi:10.1111/ecoj.12148

Hemez, P., \& Brown, S. L. (2016). Cohabitation in middle and later life. National Center for Family and Marriage Research. Bowling Green, OH. Retrieved from https://scholarworks.bgsu.edu/cgi/viewcontent.cgi?article=1062\&context=ncfmr_family_ profiles

Hemez, P., \& Manning, W. D. (2017). Thirty years of change in women's premarital cohabitation experience. National Center for Family and Marriage Research. Bowling Green, OH. Retrieved from https://www.bgsu.edu/content/dam/BGSU/college-of-artsand-sciences/NCFMR/documents/FP/hemez-manning-30-yrs-change-women-premaritalcohab-fp-17-05.pdf Isen, A., \& Stevenson, B. (2011). Women’s education and family behavior: Trends in marriage, divorce, and fertility. In J.B. Shoven (Ed.), Demography and the Economy (pp. 107-142). Chicago: University of Chicago Press.

Ishizuka, P. (2018). The economic foundations of cohabiting couples' union transitions. Demography, 55(2), 535-557. doi:10.1007/s13524-018-0651-1 
Johnson, K. M., \& Lichter, D. T. (2013). Rural retirement destinations: Natural decrease and the shared demographic destinies of elderly and Hispanics. In N. Glasgow \& E. H. Berry (Eds.), Rural Aging in 21st Century America (pp. 275-294). Dordrecht: Springer Netherlands.

Johnson, K. M., \& Lichter, D. T. (2016). Diverging demography: Hispanic and Non-Hispanic contributions to U.S. population redistribution and diversity. Population Research and Policy Review, 35(5), 705-725. doi:10.1007/s11113-016-9403-3

Joyner, K., Manning, W., \& Bogle, R. (2017). Gender and the stability of same-sex and different-sex relationships among young adults. Demography, 54(6), 2351-2374. doi:10.1007/s13524-017-0633-8

Kalmijn, M. (2012). The educational gradient in intermarriage: A comparative analysis of immigrant groups in the United States. Social Forces, 91(2), 453-476. doi:10.1093/sf/sos128

Kennedy, S., \& Ruggles, S. (2014). Breaking up is hard to count: the rise of divorce in the United States, 1980-2010. Demography, 51(2), 587-598. doi:10.1007/s13524-013-0270-9

Kim, J. (2012). Educational differences in marital dissolution: Comparison of White and African American women. Family Relations, 61(5), 811-824. doi:10.1111/j.17413729.2012.00735.x

Kolk, M., \& Andersson, G. (2018). Two decades of same-sex marriage in Sweden: A demographic account of developments in marriage, childbearing and divorce. Working 
Paper 2018:02. Stockholm University Linneaus Center on Social Policy and Family Dynamics in Europe. Stockholm. Retrieved from https://www.su.se/polopoly_fs/1.377756.1521221452!/menu/standard/file/WP_2018_02. pdf

Kulu, H., Hannemann, T., Pailhé, A., Neels, K., Krapf, S., González-Ferrer, A., \& Andersson, G. (2017). Fertility by birth order among the descendants of immigrants in selected European countries. Population and Development Review, 43(1), 31-60. doi:10.1111/padr.12037 Kuo, J. C.-L., \& Raley, R. K. (2016). Is it all about money? Work characteristics and women's and men's marriage formation in early adulthood. Journal of Family Issues, 37(8), 1046-1073. doi:10.1177/0192513X14530973

Kuperberg, A. (2014). Age at coresidence, premarital cohabitation, and marriage dissolution: 1985-2009. Journal of Marriage and Family, 76(2), 352-369. doi:10.1111/jomf.12092 Lagos, D. (2018). Looking at population health beyond "Male” and "Female”: Implications of transgender identity and gender nonconformity for population health. Demography, 55(6), 2097-2117. doi:10.1007/s13524-018-0714-3

Lamidi, E. (2016). A quarter century of change in nonmarital births: Racial/Ethnic differences. National Center for Family and Marriage Research. Bowling Green, OH. Retrieved from http://www.bgsu.edu/ncfmr/resources/data/family-profiles/lamidinonmarital-births- racial-ethnic-fp-16-04.html

This article is protected by copyright. All rights reserved. 
Lamidi, E., \& Manning, W. D. (2016). Marriage and cohabitation experiences among young adults. National Center for Family and Marriage Research. Bowling Green, OH. Retrieved from https://scholarworks.bgsu.edu/ncfmr_family_profiles/60

Lamidi, E., Manning, W. D., \& Brown, S. L. (2019). Change in the stability of first premarital cohabitation among women in the United States, 1983-2013. Demography, 56(2), 427450. doi: 10.1007/s13524-019-00765-7

Lau, C. Q. (2012). The stability of same-sex cohabitation, different-sex cohabitation, and marriage. Journal of Marriage and Family, 74(5), 973-988. doi:10.1111/j.17413737.2012.01000.x

Lee, D., \& McLanahan, S. (2015). Family structure transitions and child development: Instability, selection, and population heterogeneity. American Sociological Review, 80(4), 738-763. doi:10.1177/0003122415592129

Lewis, J. M., \& Kreider, R. M. (2015). Remarriage in the United States. ACS-30. American Community Survey Reports. U.S. Census Bureau. Washington D.C. Retrieved from https://www.census.gov/content/dam/Census/library/publications/2015/acs/acs-30.pdf.

Lichter, D. T., McLaughlin, D. K., Kephart, G., \& Landry, D. J. (1992). Race and the retreat from marriage: A shortage of marriageable men? American Sociological Review, 57(6), 781-799. doi:10.2307/2096123

Lichter, D. T., \& Qian, Z. (2008). Serial cohabitation and the marital life course. Journal of Marriage and Family, 70(4), 861-878. doi:10.1111/j.1741-3737.2008.00532.x

This article is protected by copyright. All rights reserved. 
Lichter, D. T., Qian, Z., \& Tumin, D. (2015). Whom do immigrants marry? Emerging patterns of intermarriage and integration in the United States. The Annals of the American Academy of Political and Social Science, 662(1), 57-78. doi:10.1177/0002716215594614

Lichter, D. T., Turner, R. N., \& Sassler, S. (2010). National estimates of the rise in serial cohabitation. Social Science Research, 39(5), 754-765.

doi:10.1016/j.ssresearch.2009.11.002

Liefbroer, A. C., \& Dourleijn, E. (2006). Unmarried cohabitation and union stability: Testing the role of diffusion using data from 16 European countries. Demography, 43(2), 203-221. doi:10.1353/dem.2006.0018

Livingston, G. (2015). Childlessness falls, family size grows among highly educated women. Pew Research Center. Washington, D.C. Retrieved from http://www.pewresearch.org/wpcontent/uploads/sites/3/2015/05/2015-05-07_children-ever-born_FINAL.pdf

Livingston, G. (2016). Births outside of marriage decline for immigrant women. Pew Research Center. Washington, D.C. Retrieved from http://www.pewsocialtrends.org/wpcontent/uploads/sites/3/2016/10/ST_2016.10.26_fertility_FINAL.pdf

Livingston, G. (2017). Over the past 25 years, immigrant moms bolstered births in 48 states. Pew Research Center. Washington, D.C. Retrieved from http://www.pewresearch.org/fact-tank/2017/08/29/over-the-past-25-years-immigrantmoms-bolstered-births-in-48-states/

This article is protected by copyright. All rights reserved. 
Lesthaeghe, R. J., \& Neidert, L. (2006). The second demographic transition in the United States: exception or textbook example?. Population and Development Review, 32(4), 669-698. doi:10.1111/j.1728-4457.2006.00146.x

Lesthaeghe, R., \& Van de Kaa, D. J. (1986). Two demographic transitions?. Population: Growth and Decline, 9-24.

Lesthaeghe, Ron. (2014). The second demographic transition: A concise overview of its development. Proceedings of the National Academy of Sciences, 111(51), 1811218115. doi:10.1073/pnas.1420441111

Lopoo, L. M., \& Western, B. (2005). Incarceration and the formation and stability of marital unions. Journal of Marriage and Family, 67(3), 721-734. doi:10.1111/j.17413737.2005.00165.x

Lundberg, S., Pollak, R. A., \& Stearns, J. (2016). Family inequality: Diverging patterns in marriage, cohabitation, and childbearing. Journal of Economic Perspectives, 30(2), 79102. doi:10.1257/jep.30.2.79

Manning, W. D., Brown, S. L., \& Stykes, J. B. (2014). Family complexity among children in the United States. The Annals of the American Academy of Political and Social Science, 654(1), 48-65. doi:10.1177/0002716214524515

Manning, W. D., \& Cohen, J. A. (2012). Premarital cohabitation and marital dissolution: An examination of recent marriages. Journal of Marriage and Family, 74(2), 377-387. doi:10.1111/j.1741-3737.2012.00960.x

This article is protected by copyright. All rights reserved. 
Maralani, V. (2013). The demography of social mobility: Black-white differences in the process of educational reproduction. American Journal of Sociology, 118(6), 1509-1558. doi:144.092.031.228

Martin, J. A., Hamilton, B. E., Osterman, M. J., Driscoll, A. K., \& Mathews, T. J. (2017). Births: Final data for 2015. National Vital Statistics Reports, 66(1). National Center for Health Statistics, Division of Vital statistics. Atlanta, GA. Retrieved from https://www.cdc.gov/nchs/data/nvsr/nvsr66/nvsr66_01.pdf.

Martin, S. P. (2006). Trends in marital dissolution by women's education in the United States. Demographic Research, 15(20), 537-560. doi:10.4054/DemRes.2006.15.20

Martin, S. P., Astone, N. M., \& Peters, H. E. (2014). Fewer marriages, more divergence: Marriage projections for millennials to age 40. Urban Institute. Washington, D.C. Retrieved from https://www.urban.org/sites/default/files/publication/22586/413110Fewer-Marriages-More-Divergence-Marriage-Projections-for-Millennials-to-Age-.PDF. Martinez, G.M., Daniels, K., Febo-Vazquez, I. (2018). Fertility of men and women aged 15-44 in the United States: National Survey of Family Growth, 2011-2015. National Health Statistics Report, (113), 1-16. Retrieved from https://www.cdc.gov/nchs/data/nhsr/nhsr113.pdf. Massey, D. S. (2012). Immigration and the Great Recession. Stanford Center on Poverty and Inequality. Stanford, CA. Retrieved from https://inequality.stanford.edu/sites/default/files/Immigration_fact_sheet.pdf 
Matysiak, A., Styrc, M., \& Vignoli, D. (2014). The educational gradient in marital disruption: a meta-analysis of European research findings. Population Studies, 68(2), 197-215. doi:10.1080/00324728.2013.856459

McDonald, F. P. (2013). Societal foundations for explaining fertility: Gender equity. Demographic Research, S16(34), 981-994. doi:10.4054/DemRes.2013.28.34

McLanahan, S. (2004). Diverging destinies: How children are faring under the second demographic transition. Demography, 41(4), 607-627. doi:10.1353/dem.2004.0033

McLanahan, S., \& Sandefur, G. (1984). Growing up with a single parent: What hurts, what helps. Cambridge, MA. Harvard University Press.

McNamee, C. B., \& Raley, R. K. (2011). A note on race, ethnicity and nativity differentials in remarriage in the United States. Demographic Research, 24(13), 293-312. doi:10.4054/DemRes.2011.24.13

Mernitz, S. (2018). A cohort comparison of trends in first cohabitation duration in the United States. Demographic Research, 38(66), 2073-2086. doi:10.4054/DemRes.2018.38.66 Meyer, D. R., \& Carlson, M. J. (2014). Family complexity: Implications for policy and research. The ANNALS of the American Academy of Political and Social Science, 654(1), 259-276. doi:10.1177/0002716214531385

Mitchell, C., McLanahan, S., Hobcraft, J., Brooks-Gunn, J., Garfinkel, I., \& Notterman, D. (2015). Family structure instability, genetic sensitivity, and child well-being. American Journal of Sociology, 120(4), 1195-1225.

This article is protected by copyright. All rights reserved. 
Mitchell, C., McLanahan, S., Schneper, L., Garfinkel, I., Brooks-Gunn, J., \& Notterman, D. (2017). Father loss and child telomere length. Pediatrics, 140(2), e20163245. doi:10.1542/peds.2016-3245

Monte, L. M. (2019). Multiple-partner fertility in the United States: A demographic portrait. Demography, 56(1), 103-127. doi:10.1007/s13524-018-0743-y

Morgan, S. P., Cumberworth, E., \& Wimer, C. (2011). The Great Recession's influence on fertility, marriage, divorce, and cohabitation. In D.B. Grusky et al.(Eds.), The Great Recession (pp. 220-245). New York: Russell Sage Foundation.

Musick, K., \& Michelmore, K. (2015). Change in the stability of marital and cohabiting unions following the birth of a child. Demography, 52(5), 1463-1485. doi:10.1007/s13524-0150425-y

National Center for Health Statistics. (1973). 100 years of marriage and divorce statistics, 18671967. DHEW Publication No. (HRA) 74-1902. 21(24). Retrieved from https://www.cdc.gov/nchs/data/series/sr_21/sr21_024.pdf.

National Center for Health Statistics. (2003). Live births, birth rates, and fertility rates, by race: United States, 1909-2003. Retrieved from https://www.cdc.gov/nchs/data/statab/natfinal2003.annvol1_01.pdf.

Nobles, J., Rubalcava, L., \& Teruel, G. (2015). After spouses depart: Emotional wellbeing among nonmigrant Mexican mothers. Social Science \& Medicine, 132, 236-244. doi:10.1016/j.socscimed.2014.11.009 
Obergefell v. Hodges. 2015. 135 S. Ct. 2071191 L. Ed. 2d 953, 576 U.S.

Office of Immigration Statistics. (2017). Yearbook of immigration statistics: 2017.Retrieved from https://www.dhs.gov/sites/default/files/publications/yearbook_immigration_statistics_201 7_0.pdf Office of Immigration Statistics. (2018). Illegal alien population residing in the United States: January 2015. Retrieved from https://www.dhs.gov/sites/default/files/publications/18_1214_PLCY_pops-est-report.pdf

Oppenheimer, V. K. (2003). Cohabiting and marriage during young men’s career-development process. Demography, 40(1), 127-149. doi: 10.1353/dem.2003.0006

Park, H., \& Raymo, J. M. (2013). Divorce in Korea: Trends and educational differentials. Journal of Marriage and Family, 75(1), 110-126. doi:10.1111/j.1741-3737.2012.01024.x

Parrado, E. A. (2011). How high is Hispanic/Mexican fertility in the United States? Immigration and tempo considerations. Demography, 48(3), 1059-1080. doi:10.1007/s13524-0110045-0

Passel, J. S., \& Cohn, D. V. (2016). Number of babies born to unauthorized immigrants in U.S. continued to decline in 2014. Pew Research Center. Washington, D.C. Retrieved from http://www.pewresearch.org/fact-tank/2016/10/26/number-of-babies-born-tounauthorized-immigrants-in-u-s-continues-to-decline/

This article is protected by copyright. All rights reserved. 
Passel, J. S., Cohn, D. V., \& Gonzalez-Barrera, A. (2012). Net migration from Mexico falls to zero-and perhaps less. Pew Hispanic Center. Washington, D.C. Retrieved from http://www.qqq-zzz.com/system/files/Pew-Net_Migration_from_Mexico_Falls_to_Zero.pdf

Payne, K. K. (2018). Change in the U.S. remarriage rate, 2008 \& 2016. National Center for Family and Marriage Research. Bowling Green, OH. Retrieved from https://www.bgsu.edu/content/dam/BGSU/college-of-arts-andsciences/NCFMR/documents/FP/payne-change-remarriage-rate-fp-18-16.pdf

Perkins, K. L. (2019). Changes in household composition and children’s educational attainment. Demography. doi:10.1007/s13524-018-0757-5

Phillips , J. A., \& Sweeney, M. M. (2005). Premarital cohabitation and marital disruption among white, black, and Mexican American women. Journal of Marriage and Family, 67(2), 296-314. doi:10.1111/j.0022-2445.2005.00117.x

Pilkauskas, N. V., \& Cross, C. (2018). Beyond the nuclear family: Trends in children living in shared households. Demography, 55(6), 2283-2297. doi:10.1007/s13524-018-0719-y

Qian, Z., Glick, J. E., \& Batson, C. D. (2012). Crossing boundaries: nativity, ethnicity, and mate selection. Demography, 49(2), 651-675. doi:10.1007/s13524-012-0090-3

Qian, Z., \& Lichter, D. T. (2007). Social boundaries and marital assimilation: Interpreting trends in racial and ethnic intermarriage. American Sociological Review, 72(1), 68-94. doi:10.1177/000312240707200104

This article is protected by copyright. All rights reserved. 
Rackin, H. M., \& Gibson-Davis, C. M. (2018). Social class divergence in family transitions: The importance of cohabitation. Journal of Marriage and Family, 80(5), 1271-1286. doi:10.1111/jomf.12522

Radford, J. (2019). Key findings about U.S. immigrants. Pew Research Center. Washington, D.C. Retrieved from https://www.pewresearch.org/fact-tank/2019/06/17/key-findings-about-us-immigrants/

Radford, J., \& Noe-Bustamante, L. (2019). Facts on U.S. immigrants, 2017. Pew Research Center. Washington, D.C. Retrieved from https://www.pewhispanic.org/2019/06/03/facts-on-u-s-immigrants/\#fb-key-chartspopulation

Rackin, H. M., \& Gibson-Davis, C. M. (2018). Social class divergence in family transitions: The importance of cohabitation. Journal of Marriage and Family, 80(5), 1271-1286. doi:10.1007/s13524-013-0270-9

Raley, R. K., Sweeney, M. M., \& Wondra, D. (2015). The growing racial and ethnic divide in U.S. marriage patterns. The Future of Children, 25(2), 89-109. doi:10.1353/foc.2015.0014

Reinhold, S. (2010). Reassessing the link between premarital cohabitation and marital instability. Demography, 47(3), 719-733. doi:10.1353/dem.0.0122 
Rodriguez, N. \& Hagan, J. M. (2004). Fractured families and communities: Effects of immigration reform in Texas, Mexico, and El Salvador. Latino Studies, 2(3), 328-351. doi:10.1057/palgrave.lst.8600094

Romero, A. P. (2017). 1.1 Million LGBT adults are married to someone of the same sex at the two-year anniversary of Obergefell V. Hodges. The Williams Institute. UCLA School of Law. Los Angeles. Retrieved from https://williamsinstitute.law.ucla.edu/wpcontent/uploads/Obergefell-2-Year-Marriages.pdf

Rosenfeld, M. J. (2010). Nontraditional families and childhood progress through school. Demography, 47(3), 755-775. doi:10.1353/dem.0.0112

Rosenfeld, M. J. (2014). Couple longevity in the era of same-sex marriage in the United States. Journal of Marriage and Family, 76(5), 905-918. doi:10.1111/jomf.12141

Rosenfeld, M. J., \& Roesler, K. (2019). Cohabitation experience and cohabitation's association with marital dissolution. Journal of Marriage and Family, 81(1), 42-58. doi:10.1111/jomf.12530

Ruggles, S. (1997). The rise of divorce and separation in the United States, 1880-1990. Demography, 34(4), 455-466. doi:10.2307/3038300

Sassler, S., Michelmore, K., \& Qian, Z. (2018). Transitions from sexual relationships into cohabitation and beyond. Demography, 55(2), 511-534. doi:10.1007/s13524-018-0649-8

Sassler, S., \& Miller, A. J. (2017). Cohabitation nation: Gender, class, and the remaking of relationships. Oakland, California: University of California Press.

This article is protected by copyright. All rights reserved. 
Schaller, J. (2013). For richer, if not for poorer? Marriage and divorce over the business cycle. Journal of Population Economics, 26(3), 1007-1033. doi:10.1007/s00148-012-0413-0

Schneebaum, A., \& Badgett, M. V. L. (2019). Poverty in US lesbian and gay couple households. Feminist Economics, 25(1)1-30. doi:10.1080/13545701.2018.1441533

Schneider, D. (2017). The effects of the Great Recession on American families. Sociology Compass, 11(4), 1-11. doi:10.1111/soc4.12463

Schneider, D., Harknett, K., \& Stimpson, M. (2019). Job quality and the educational gradient in entry into marriage and cohabitation. Demography, 56(2), 451-476. doi:10.1007/s13524018-0749-5

Schneider, D., \& Hastings, O. P. (2015). Socioeconomic variation in the effect of economic conditions on marriage and nonmarital fertility in the United States: Evidence from the Great Recession. Demography, 52(6), 1893-1915. doi:10.1007/s13524-015-0437-7

Schoen, R. (2016). The continuing retreat of marriage: Figures from marital status life tables for United States females, 2000-2005 and 2005-2010. In R. Schoen (Ed.), Dynamic Demographic Analysis (pp. 203-215). New York: Springer.

Schoen, R., \& Standish, N. (2001). The retrenchment of marriage: Results from marital status life tables for the United States, 1995. Population and Development Review, 27(3), 553563. doi:10.1111/j.1728-4457.2001.00553.x

This article is protected by copyright. All rights reserved. 
Schwartz, C. R., \& Han, H. (2014). The reversal of the gender gap in education and trends in marital dissolution. American Sociological Review, 79(4), 605-629. doi:10.1177/0003122414539682

Scott, M. E., Peterson, K., Ikramullah, E., \& Manlove, J. (2013). Multiple partner fertility among unmarried nonresident fathers. In C. S. Tamis-LeMonda \& N. Cabrera (Eds.), Handbook of father involvement: Multidisciplinary perspectives (2nd ed., pp. 97-115). Mahwah, N.J.: Lawrence Erlbaum Associates.

Seltzer, N. (2019). Beyond the Great Recession: Labor market polarization and ongoing fertility decline in the United States. Demography, 56(4), 1463-1493. doi:10.1007/s13524-01900790-6

Shang, Q., \& Weinberg, B. A. (2013). Opting for families: recent trends in the fertility of highly educated women. Journal of Population Economics, 26(1), 5-32. doi:10.1007/s00148012-0411-2

Smock, P. J. (2000). Cohabitation in the United States: An appraisal of research themes, findings, and implications. Annual Review of Sociology, 26, 1-20. doi:10.1146/annurev.soc.26.1.1

Smock, P. J., \& Manning, W. D. (1997). Cohabiting partners’ economic circumstances and marriage. Demography, 34(3), 331-341. doi:10.2307/3038287

This article is protected by copyright. All rights reserved. 
Smock, P. J., Manning, W. D., \& Porter, M. (2005). "Everything's there except money": How money shapes decisions to marry among cohabitors. Journal of Marriage and Family, 67(3), 680-696. doi:10.1111/j.1741-3737.2005.00162.x

Sobotka, T., Skirbekk, V., \& Philipov, D. (2011). Economic recession and fertility in the developed world. Population and Development Review, 37(2), 267-306. doi:10.1111/j.1728-4457.2011.00411.x

Stevens, G., Ishizawa, H., \& Escandell, X. (2012). Marrying into the American population: Pathways into cross-nativity marriages. International Migration Review, 46(3), 740-759. doi:10.1111/j.1747-7379.2012.00903.x

Stykes, J. B., \& Guzzo, K. B. (2019). Multiple-partner fertility: Variation across measurement approaches. In R. Schoen (Ed.), Analytical Family Demography (pp. 215-239). New York: Springer.

Stykes, J. B., \& Williams, S. (2013). Diverging destinies: Children's family structure variation by maternal education. National Center for Family and Marriage Research. Bowling Green, OH. Retrieved from https://www.bgsu.edu/content/dam/BGSU/college-of-artsand-sciences/NCFMR/documents/FP/FP-13-16.pdf

Suárez-Orozco, C., Bang, H. J., \& Kim H. Y. (2011). I felt like my heart was staying behind: Psychological implications of family separations and reunifications for immigrant youth. Journal of Adolescent Research, 26(2), 222-257. doi:10.1177/0743558410376830

This article is protected by copyright. All rights reserved. 
Sweeney, M. M. (2010). Remarriage and stepfamilies: Strategic sites for family scholarship in the 21st century. Journal of Marriage and Family, 72(3), 667-684. doi:10.1111/j.17413737.2010.00724.x

Sweeney, M. M., \& Phillips, J. A. (2004). Understanding racial differences in marital disruption: Recent trends and explanations. Journal of Marriage and Family, 66(3), 639-650. doi:10.1111/j.0022-2445.2004.00043.x

Sweeney, M. M., \& Raley, R. K. (2014). Race, ethnicity, and the changing context of childbearing in the United States. Annual Review of Sociology, 40, 539-558. doi:10.1146/annurev-soc-071913-043342

Thomson, E., Lappegard, T., Carlson, M., Evans, A., \& Gray, E. (2014). Childbearing across partnerships in Australia, the United States, Norway, and Sweden. Demography, 51(2), 485-508. doi:10.1007/s13524-013-0273-6

Tumin, D., \& Qian, Z. (2017). Unemployment and the transition from separation to divorce. Journal of Family Issues, 38(10), 1389-1413. doi:10.1177/0192513x15600730

U.S. Census Bureau. (2016). Household characteristics of same-sex couple households by relationship type: 2016 American Community Survey. Retrieved from https://www.census.gov/content/census/en/data/tables/time-series/demo/same-sexcouples/ssc-house-characteristics.html

U.S. Census Bureau. (2017a). Household characteristics of same-sex couple households by relationship type: 2017. Retrieved from

This article is protected by copyright. All rights reserved. 
https://www.census.gov/content/census/en/data/tables/time-series/demo/same-sexcouples/ssc-house-characteristics.html

U.S. Census Bureau. (2017b). Table C3: Living arrangements of children under 18 years and marital status of parents, by age, sex, race, and Hispanic origin and selected characteristics of the child for all children: 2017. America's families and living arrangements: 2017. Retrieved from https://www.census.gov/content/census/en/data/tables/2017/demo/families/cps-2017.html

U.S. Census Bureau. (2018a). Table AD-3: Living arrangements of adults 18 and over, 1967 to present. Historical living arrangements of adults. Retrieved from https://www.census.gov/data/tables/time-series/demo/families/adults.html

U.S. Census Bureau. (2018b). Historical marital status tables. Retrieved from https://www.census.gov/data/tables/time-series/demo/families/marital.html

U.S. Census Bureau. (2018c). Historical living arrangements of children. Retrieved from https://www.census.gov/data/tables/time-series/demo/families/children.html

U.S. Census Bureau. (2018d). Table C8: Poverty status, food stamp receipt, and public assistance for children under 18 years by selected characteristics. America's families and living arrangements:2018. Retrieved from https://www.census.gov/data/tables/2018/demo/families/cps-2018.html

Vere, J. P. (2007). "Having it all" no longer: fertility, female labor supply, and the new life choices of generation X. Demography, 44(4), 821-828. doi:10.1353/dem.2007.0035

This article is protected by copyright. All rights reserved. 
Villarreal, A. (2014). Explaining the decline in Mexico-U.S. Migration: the effect of the Great Recession. Demography, 51(6), 2203-2228. doi:10.1007/s13524-014-0351-4

Wiemers, E. E., Seltzer, J. A., Schoeni, R. F., Hotz, V. J., \& Bianchi, S. M. (2019).

Stepfamily structure and transfers between generations in US families. Demography, 56(1), 229- 260. doi:10.1007/s13524-018-0740-1

Wiik, K. A., Seierstad, A., \& Noack, T. (2014). Divorce in Norwegian same-sex marriages and registered partnerships: The role of children. Journal of Marriage and Family, 76(5), 919-929. doi:10.1111/jomf.12132

Wilson, W. J. (1987). The truly disadvantaged: The inner city, the underclass, and public policy. Chicago: University of Chicago Press.

World Bank. (2019). Fertility rate, total (births per woman). Retrieved from https://data.worldbank.org/indicator/SP.DYN.TFRT.IN

Wright, L. (2018). Union transitions and fertility within first premarital cohabitations in Canada: Diverging patterns by education? Demography, 56(1), 151-161. doi:10.1007/s13524-0180741-0

Wu, H. (2017). Trends in births to single and cohabiting mothers, 1980-2014. National Center for Family and Marriage Research. Bowling Green, OH. Retrieved from https://www.bgsu.edu/content/dam/BGSU/college-of-arts-andsciences/NCFMR/documents/FP/wu-trends-births-single-cohab-mothers-fp-17-04.pdf

This article is protected by copyright. All rights reserved. 
Wu, H. (2018). Grandchildren living in a grandparent-headed household. National Center for Family and Marriage Research. Bowling Green, OH. Retrieved from https://www.bgsu.edu/content/dam/BGSU/college-of-arts-andsciences/NCFMR/documents/FP/wu-grandchildren-living-with-grandparent-hhh-fp-1801.pdf

Xie, Y., Raymo, J. M., Goyette, K., \& Thornton, A. (2003). Economic potential and entry into marriage and cohabitation. Demography, 40(2), 351-367. doi:10.1353/dem.2003.0019

Zobl, S. R., \& Smock, P. J. (2015). Multiple partner fertility among white married couples in the U.S., 1955. National Center for Family and Marriage Research. Bowling Green, OH. Retrieved from https://scholarworks.bgsu.edu/cgi/viewcontent.cgi?article=1066\&context=ncfmr_family_ profiles

This article is protected by copyright. All rights reserved. 
Figure 1. MEdian Age AT First MARriage (1890-2018) ANd PERCENT Of AdUlts Living With SPOUSE (1967-2018).

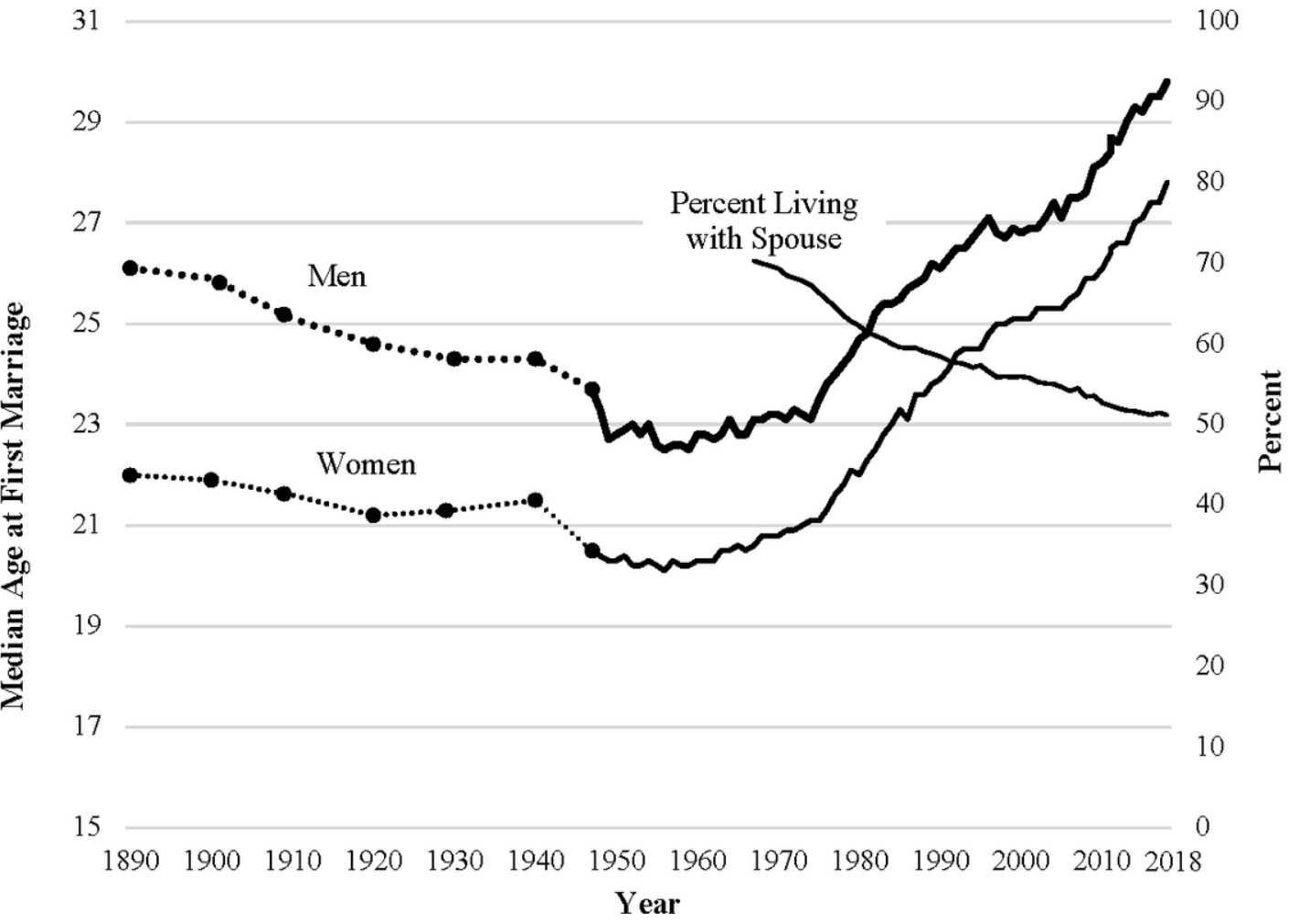

Notes: Dashed lines between years are linearly interpolated between data points.

Sources: Median age at first marriage: U.S. Census Bureau (2018b). Percent of adults age 18 and over living with spouse: U.S. Census Bureau (2018a).

JOMF_12612_SmockSchwartz_DIRFigures_revv3_Page_1.tiff

This article is protected by copyright. All rights reserved. 
FIGURE 2. REFINED DiVORCE RATE (DIVORCES PER 1,000 MARRIED WOMEN): 1890-2017. 25.0

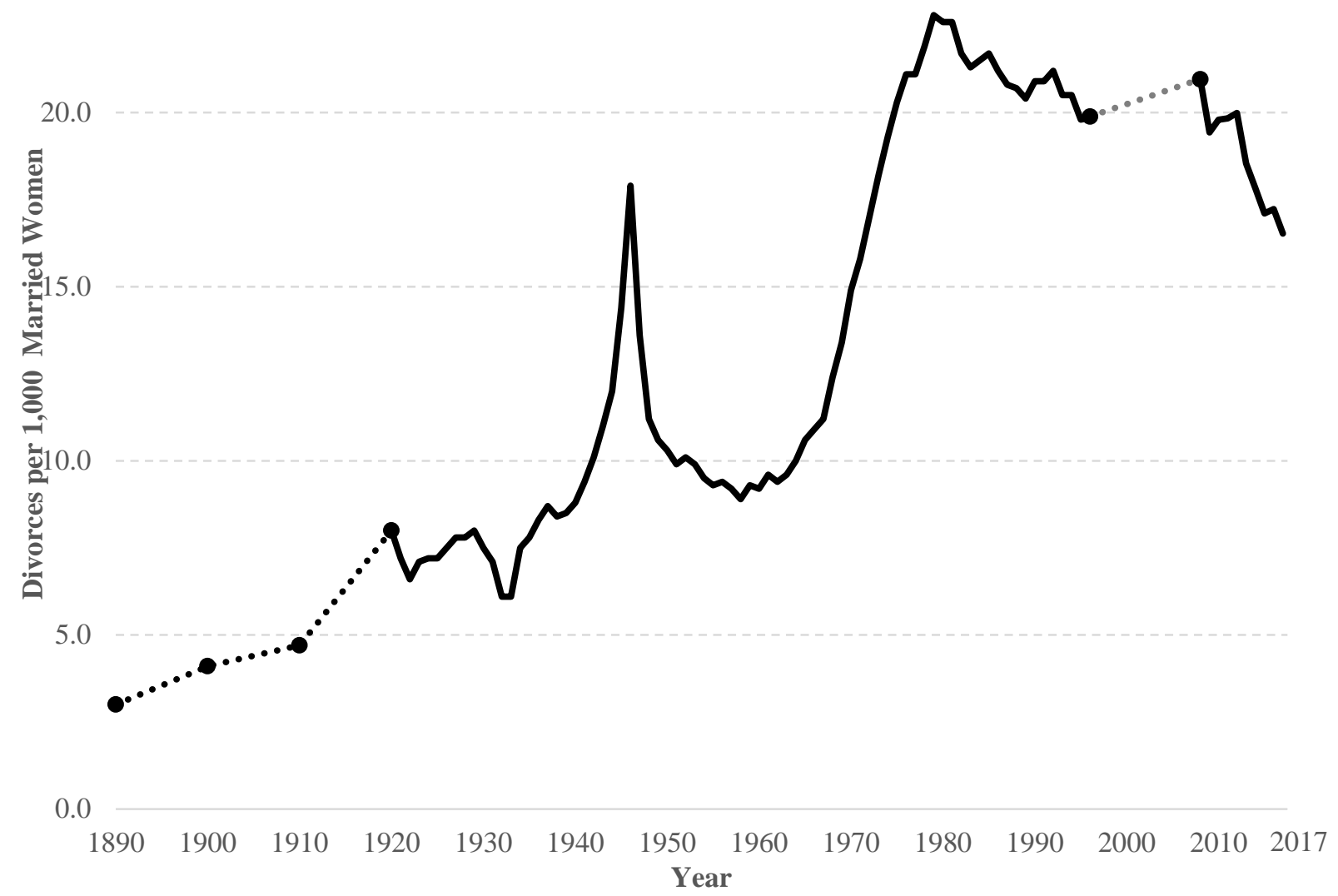

Notes: Dashed lines between years are linearly interpolated between data points.

Sources: 1890-1920: decennial divorces per 1,000 married women aged 15+, National Center for Health Statistics, (1973:Table 1); 1920-1995: annual divorces per 1,000 married women aged 15+, Haines (2006:1-688, 1-689); 2008-2017: annual number of women aged 15+ who divorced in the previous 12 months / annual number of married women aged 15+, American Community Survey, Ruggles et al. (2018). 
Figure 3. Percentage OF WOMEn (15-44) Who CoHABited With Their First Husband, By MARRIAGE COHORT AND EDUCATIONAL ATTAINMENT.

$$
\text { घH.S. } \quad \text { H.S./GED } \square \text { Some College } \quad \text { Bachelor's or higher }
$$

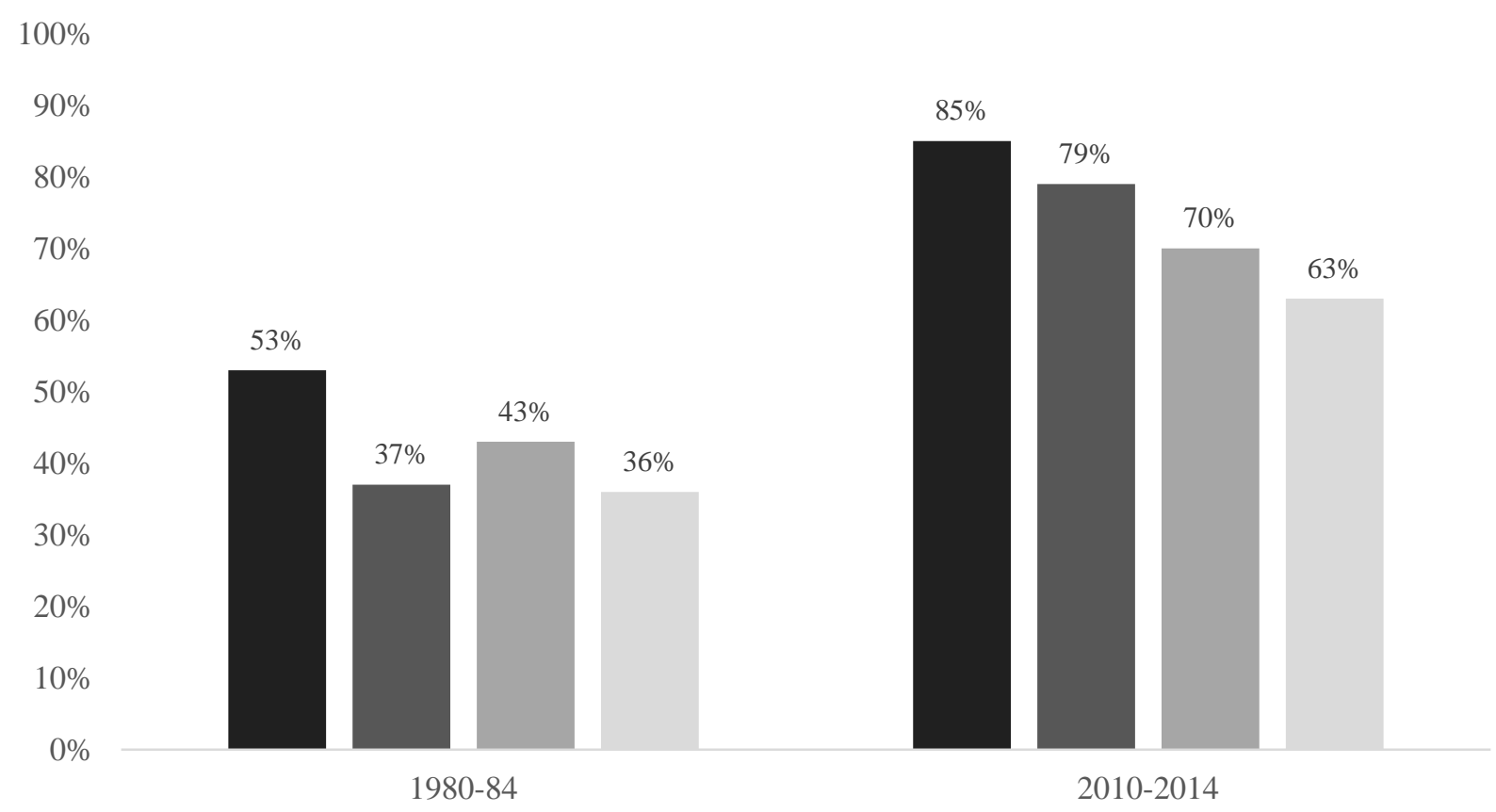

Sources: 1980-1984 Marriage Cohort: 1988 NSFG; 2010-2014 Marriage Cohort: 2011/2015 NSFG; reproduced from Hemez and Manning (2017:Figure 3). 
FIGURE 4. GENERAL FERTILITY RATE (BIRTHS PER 1,000 WOMEN AGE 15-44): 1909-2018.

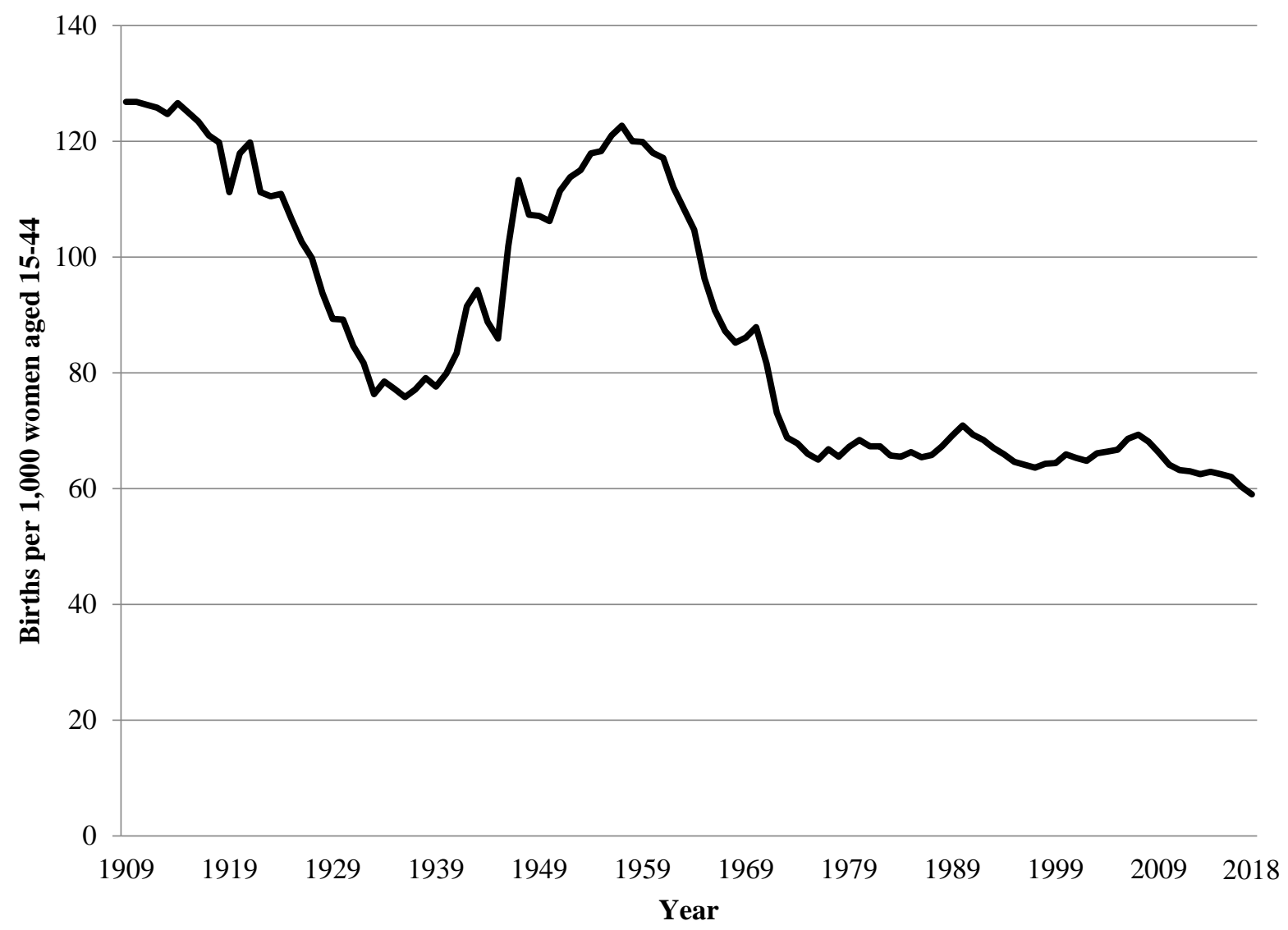

Sources: 1909-2003: National Center for Health Statistics (2003:Table 1-1); 2003-2015: Martin et al. (2017:Table 1); 2016: Hamilton et al. (2018); 2017-2018: Hamilton et al. (2019).

This article is protected by copyright. All rights reserved. 